\title{
Patent litigation in Europe
}

\author{
Katrin Cremers ${ }^{1} \cdot$ Max Ernicke ${ }^{2} \cdot$ Fabian Gaessler $^{3}$. \\ Dietmar Harhoff ${ }^{3}$ - Christian Helmers ${ }^{4}$. \\ Luke McDonagh ${ }^{5} \cdot$ Paula Schliessler $^{1}$. \\ Nicolas van Zeebroeck ${ }^{6}$
}

(c) The Author(s) 2016. This article is published with open access at Springerlink.com

\begin{abstract}
We compare patent litigation cases across four European jurisdictionsGermany, the UK (England and Wales), France, The Netherlands-using case-level data gathered from cases filed in the four jurisdictions during the period 2000-2008. Overall, we find substantial differences across jurisdictions in terms of caseloadsnotably, courts in Germany hear by far the largest number of cases, not only in absolute terms, but also when taking macro-economic indicators into account-and we further find important cross-country variances in terms of case outcomes. Moreover, we show empirically that a considerable number of patents are litigated across multiple European jurisdictions; and further, that in the majority of these cases divergent case outcomes are reached across the different jurisdictions, suggesting that the long-suspected problem of inconsistency of decision-making in European patent litigation is in fact real. Finally, we note that the coming into force
\end{abstract}

\footnotetext{
The paper was presented at a workshop at CIPA in London and the Institute for Prospective Technological Studies of the European Commission in Seville. We thank participants for helpful comments. We thank in particular the editors and three anonymous referees for their comments which substantially improved this paper. The project was financially supported by the research program Strengthening Efficiency and Competitiveness in the European Knowledge Economies (SEEK) launched by the state government of Baden-Wuerttemberg Germany and was also supported by the UK Intellectual Property Office.
}

Dietmar Harhoff

dietmar.harhoff@ip.mpg.de

1 ZEW, Mannheim, Germany

2 Universität Düsseldorf, Düsseldorf, Germany

3 Max Planck Institute for Innovation and Competition, Munich, Germany

4 Santa Clara University, Santa Clara, CA, USA

5 City University, London, UK

6 Université Libre de Bruxelles, Brussels, Belgium 
of the Unified Patent Court in Europe may, in the long term, help to alleviate this inconsistency problem.

Keywords Patent litigation - Europe · Patent system · Enforcement ·

Unified patent court

JEL Classification $\mathrm{O} 34 \cdot \mathrm{K} 11 \cdot \mathrm{K} 41$

\section{Introduction}

At present, the European patent system is undergoing a series of major reforms with the aim of "unifying" (or rather "defragmenting") the patent litigation system. It currently operates on a national basis, rather than a trans-national one, with national courts possessing the right to adjudicate patent disputes within their territories. ${ }^{* * *}{ }^{1}$ The current fragmented system is often criticized for creating unnecessary costs and complexities for patent litigants (Harhoff 2009).

The new EU-led reforms will create a European Patent with Unitary effect (EPU, also known as the unitary patent) in all member states of the European Union that have adopted the reform package, as well as a Unified Patent Court (UPC), which will be competent to issue judgments with unitary effect across all participating jurisdictions. $^{2}$ By locating court venues across the participating EU member states - including a range of local, regional and central divisions - the UPC aims to strike a balance between the legal certainty provided by the centralization of the adjudication of patent disputes across Europe and the benefits of local adjudication of patent disputes. ${ }^{3}$

\footnotetext{
${ }^{1}$ Text of the European Patent Convention, of 5 October 1973, as revised by the Act revising Article 63 EPC of 17 December 1991, and the Act revising the EPC of 29 November 2000.

${ }^{2}$ Spain, Poland and Croatia are currently the only EU member countries not participating in the Unified Patent Court, which thus covers 25 out of 28 EU member states. At present, Spain and Croatia are the only EU member states that have not signed up to the European patent with unitary effect, or unitary patent (since Italy has dropped its opposition and joined up). See Regulation (EU) No. 1257/2012 of the European Parliament and of the Council of 17 December 2012 implementing enhanced cooperation in the area of the creation of unitary patent protection; Council regulation (EU) No. 1260/2012 of 17 December 2012 implementing enhanced cooperation in the area of the creation of Unitary patent protection with regard to the applicable translation arrangements-both documents accessible at http://ec.europa.eu/ internal_market/indprop/patent/documents/index_en.htm. See also Agreement on a Unified Patent Court 2013/C 175/01 (http://eurlex.europa.eu/LexUriServ/LexUriServ. do?uri = OJ:C:2013:175:0001:0040: EN:PDF). For a further explanation of the changes see the European Patent Office (EPO) website-http:// www.epo.org/law-practice/unitary.html.

${ }^{3}$ The UPC consists of a Court of First Instance and a Court of Appeal. The Court of First Instance comprises a Central division and several local and regional divisions. The central division has its seat in Paris with specialized sections in London (chemical and pharmaceutical patents) and Munich (mechanical engineering). The Court of Appeal has its seat in Luxembourg.
} 
Over the past few years, policy makers, academics and practitioners have debated the merits of the patent reform package, and the UPC in particular. One recurring point of discussion has been the fact that although the UPC is in some respects a unified patent litigation system-with infringement and validity issues potentially decided simultaneously by the same court-it nevertheless allows for bifurcation to occur in some circumstances, an unusual situation that reflects the influence of the German patent litigation system, as explored below. ${ }^{4}$

Other major concerns commentators have with the reforms center on the questions of (i) whether the package will actually reduce the fragmentation and complexity inherent in the current European patent system (in light of the fact that not all EU member states are participating in the UPC, and that national courts will share jurisdiction with the UPC for a transitional period of at least 7 years) and (ii) whether the reforms will actually lower the costs for judicial proceedings in practice-thereby creating greater access to patent enforcement services, especially for small and medium size enterprises (SMEs)—without creating incentives for welfare-reducing litigation activities. Even now, with the new system due to come into being in 2016 or 2017 these questions remain largely unresolved, due to the complexities surrounding choice of litigation venue during the transition periodwhich is to be taken by claimants-as well as concerns over the costs of proceedings and possible "forum-shopping" by patent litigants, including so-called Nonpracticing entities (NPEs) or "patent trolls". 5

One key point that we seek to make at the outset is that over the past few years the debate about reforming the European patent litigation system has been characterized by extensive and frequent use of (often controversial) anecdotal evidence. Indeed, the debate has been undercut by a lack of analytical insights derived from actual empirical data analysis - a deficiency that is explained by the fact that systematic and comparable data concerning patent litigation in Europe has not been available to researchers (a situation which stands in stark contrast to the US, where extensive empirical evidence on patent litigation exists and is accessible to researchers).

As a result, there has been no evidence-based statistical evaluation of the need for specific litigation reforms in Europe, or of the likely impact of such reforms on litigation outcomes. For example, an important argument put forward by the proponents of the UPC is that the existence of the new court will cut down on the duplication of court cases across different European jurisdictions; and in doing so,

\footnotetext{
${ }^{4}$ The validity of a patent may be challenged before the Central division or a local/regional division, whereas infringement claims will be filed at local/regional divisions (unless the defendant is not an EU resident). In the case of a counterclaim for invalidity filed during infringement proceedings before a local/ regional division, the local/regional division has discretion to refer the validity challenge to the Central division. The fact that invalidity claims can only be filed at the Federal Patent Court after an opposition at the German Patent and Trademark Office (DPMA) or the EPO (or after the period for an opposition has expired) may further delay the decision on validity.

5 The UPC Rules of Procedure were finalized in October 2015 see http://www.unified-patent-court.org/ images/documents/UPC-Rules-of-Procedure.pdf (last visited 05 Nov 2015). For analysis of the challenges of the new system, including the issues of forum-shopping and "patent troll litigation" see L. McDonagh, 'Exploring perspectives of the Unified Patent Court and the Unitary Patent within the Business and Legal Communities' A Report Commissioned by the UK Intellectual Property Office (July 2014); https://www. gov.uk/government/publications/exploring-perspectives-of-the-up-and-upc (last visited 05 Nov 2015).
} 
will reduce the uncertainty created by the existence of different outcomes on essentially the same case (and same patent) in different jurisdictions. However, given the lack of comprehensive statistics on cross-border patent litigation, how can the merits of this argument be assessed?

In this article, we present evidence based on a newly gathered dataset of empirical patent case data - a comprehensive dataset which enables us to undertake a direct comparison between patent litigation in the four major patent litigation systems in Europe: Germany, the UK (England and Wales), ${ }^{6}$ France, and The Netherlands for the period 2000-2008. ${ }^{7}$ Importantly, our study differs from, and improves upon, the existing available data and literature, which generally is based on much more limited data samples than we provide in this article. ${ }^{8}$ Moreover, the present article is the first one in Europe to offer a view of the parties involved in patent litigation (litigant-level analysis), something which greatly enriches our study.

In undertaking our analysis, we note that there are important differences in the legal systems in these four jurisdictions, something that makes any comparison a challenging task. The most obvious difference between these four systems is that the German patent litigation system is bifurcated, i.e., infringement and validity are handled separately at different courts. The other three legal systems combine adjudication of both validity and infringement within the same court action. Since the UPC allows for bifurcation, the comparison undertaken in this article, between the bifurcated litigation system in Germany and the litigation systems in the other jurisdictions which do not feature bifurcation, provides useful insights with regard to some of the benefits expected from introducing the UPC.

In order to undertake our analysis, we collected case-level patent litigation data directly from court records and a range of other sources in all four jurisdictions for the period 2000-2008. We collected the data in a harmonized way in order to ensure comparability - a major challenge given the variances in legal procedures across the four jurisdictions. The results we provide in this article point to a number of

\footnotetext{
6 The UK contains the legal systems of England \& Wales, Scotland and Northern Ireland. Our data solely refer to the UK's major patent jurisdiction of England and Wales (also known as Britain), where the vast majority of UK patent litigation is undertaken. For the purposes of simplicity and to enable a direct country-comparison with the other jurisdictions of Germany, France and the Netherlands, we refer to the jurisdiction of England \& Wales as the UK throughout this paper.

7 The objective of this study is to cover all patent cases filed at the courts covered by our investigation during the period 2000-2008. These cases may have been decided after 2008; since our data collection occurred between 2010 and 2012, decisions made after 2008 for cases filed 2000-2008 are covered within our dataset. However, in its current form, the data we possess for the Netherlands and France do not cover all cases filed, but are largely restricted to cases that were adjudicated.

${ }^{8}$ For example, Harhoff (2009) relies mostly on practitioner estimates and estimates drawn from already existing literature. Our dataset is much broader than this. The paper closest to ours is a recent study by Graham and van Zeebroeck (GVZ) (2014). Their empirical analysis covers seven countries, including the four considered in our present article. Our data collection and analysis can be differentiated from the GVZ paper in several ways: first, our data for Germany and the UK is derived from direct case records, available from paper records or online, whereas GVZ rely on a database produced by an IP analysis company (GVZ's data cover only about $50 \%$ of the German cases and the GVZ article lacks data on settlements); second, whereas GVZ's analysis is performed at the judgment level (i.e., court decisions, or adjudications), our study is based on data aggregated at the case level; this article offers an important cross-check on the accuracy of the results reported in GVZ.
} 
differences in litigation patterns and outcomes across the four jurisdictions, some of which challenge conventional wisdom regarding patent litigation in Europe.

In this article, for the first time, we provide accurate, comparative case-level data and litigant-level data for the four major patent jurisdictions of Europe-Germany, the UK, France and The Netherlands. Overall, for the period 2000-2008 we find substantial differences across jurisdictions in terms of caseloads-notably, courts in Germany hear by far the largest number of cases, not only in absolute terms, but also when taking macro-economic indicators into account-and we further find important cross-country variances in terms of case outcomes. Moreover, we show empirically that a considerable number of patents are litigated across multiple European jurisdictions; and further, that in the majority of these cases divergent case outcomes are reached across the different jurisdictions, suggesting that the longsuspected problem of inconsistency of decision-making in European patent litigation is in fact real. Finally, we note that the coming into force of the UPC in Europe may, in the long term, help to alleviate this inconsistency problem.

Following this introductory section, the remainder of this paper is organized as follows: Sect. 2 discusses relevant differences in the four legal systems; Sect. 3 describes the collection of our litigation data and the construction of the dataset used in our analysis; Sect. 4 contains our comparison of litigation across European jurisdictions; and finally, Sect. 5 offers some concluding remarks.

\section{Enforcement systems}

This section explains briefly the main characteristics of the four enforcement systems and highlights some of the substantive and procedural differences that exist between the jurisdictions of Germany, the UK, France and The Netherlands.

\subsection{Germany}

The German patent system is illustrated in Fig. 1.

In Germany twelve regional courts, Landgerichte (LGs), are competent to hear patent and utility model infringement cases. ${ }^{9}$ Appeals against the decisions of the LGs are heard by the higher regional courts (Oberlandesgericht-OLG). Against the decisions of the higher regional courts, a second appeal can be brought before the Federal Court of Justice (Bundesgerichtshof-BGH).

The LGs have no jurisdiction to decide on the validity of a patent-neither in form of a defense against a patentee's claims for patent infringement nor in form of a (counter-) claim for declaratory judgment of invalidity. This is referred to as bifurcation of infringement and validity proceedings. ${ }^{10}$ In both patent and utility

\footnotetext{
${ }^{9}$ Berlin, Braunschweig, Düsseldorf, Erfurt, Frankfurt, Hamburg, Leipzig, Magdeburg, Mannheim, Munich I, Nuremberg-Fürth and Saarbrücken. See § 143 PatG and $\S 27$ GebrMG and the relevant regulations of the respective federal states.

${ }^{10}$ The situation is different for infringement suits on the basis of utility models in which the defendant is allowed to raise an invalidity defense. See BGH, Opinion dated June 5, 1997-X ZR 139/95, BGHZ 136, 40, 42-Leiterplattennutzen (English translation not available).
} 


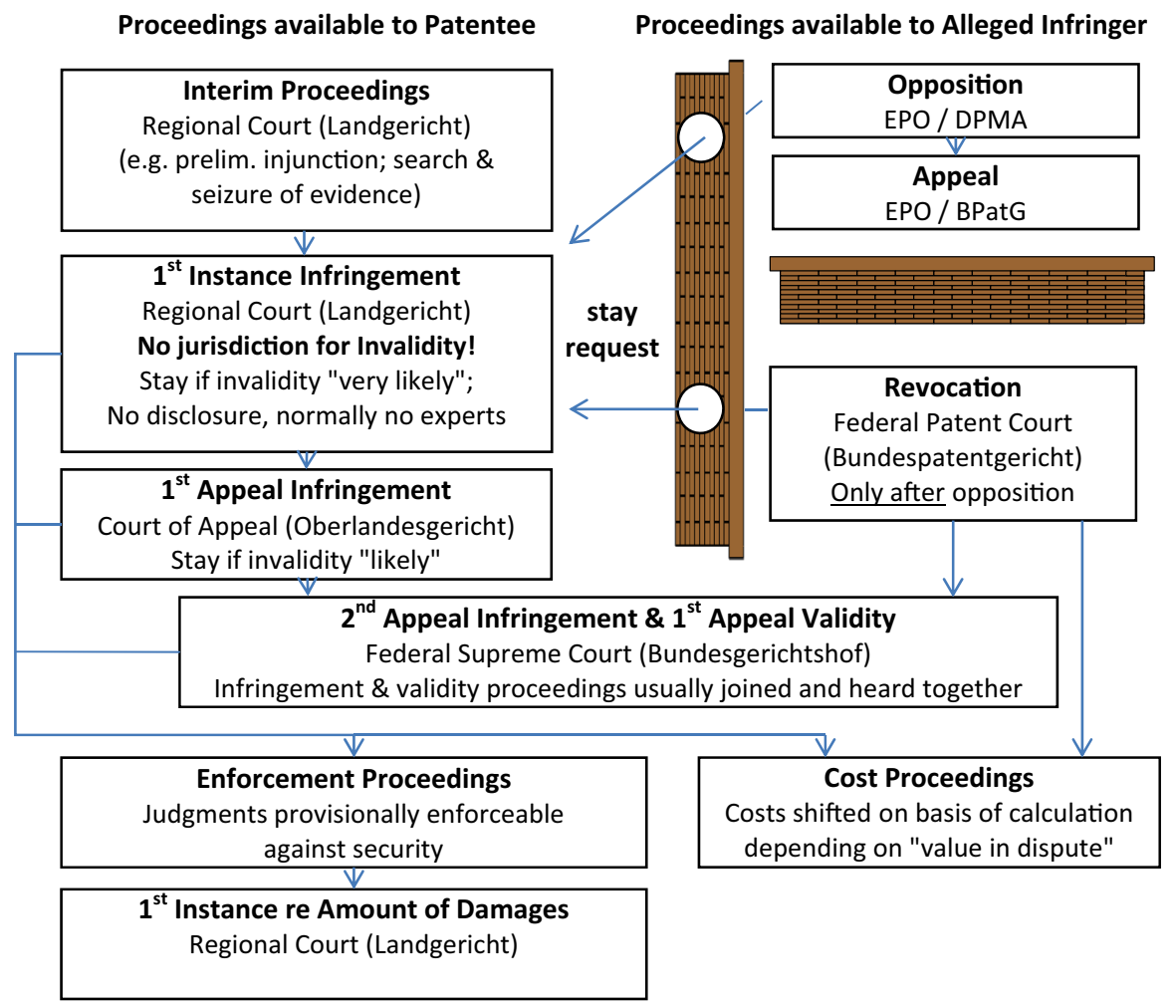

Fig. 1 Overview of the patent litigation system in Germany

model infringement proceedings the infringement court has the discretion to stay the proceedings until parallel revocation proceedings before EPO, DPMA (Deutsches Patent- und Markenamt) and BPatG (Bundespatentgericht) have come to a conclusion. $^{11}$

As in all contracting states of the EPC, the validity of an EP can be challenged by filing an opposition before the EPO. The validity of a DE patent may be challenged by filing an opposition before the DPMA. ${ }^{12}$ The decisions of the DPMA can then be appealed before the Federal Patent Court. ${ }^{13}$ Only after the deadline for filing an opposition against a DE patent or EP have lapsed and all pending opposition and appeal proceedings against the patent have been terminated, can a revocation action against an EP and DE patent be filed before the BPatG. ${ }^{14}$ The decisions of the BPatG can be appealed before the BGH. Therefore, the BGH is the only court in Germany which has jurisdiction to decide on both infringement and validity.

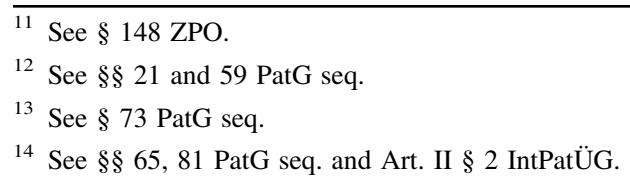


Proceedings available to Patentee

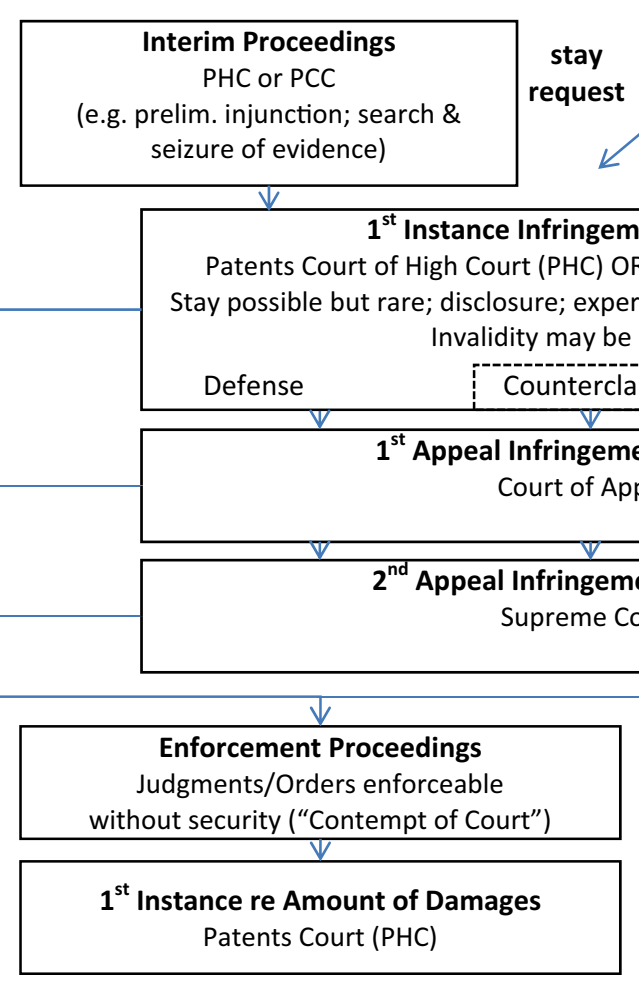

Proceedings available to Alleged Infringer

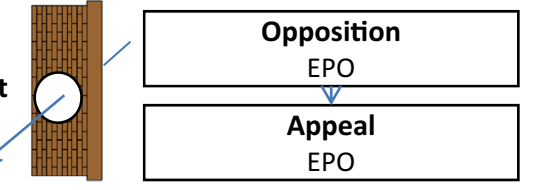


Table 1 Comparison of patent litigation systems

\begin{tabular}{|c|c|c|c|c|}
\hline Features & $\mathrm{DE}$ & FR & NL & UK \\
\hline First instance courts & $\begin{array}{c}12 \text { (+1 for } \\
\text { validity) }\end{array}$ & $\begin{array}{l}1 \text { (10 before } \\
\text { '09) }\end{array}$ & 1 & 2 \\
\hline Appeals court & $\begin{array}{l}1 / 1(+1 \text { for } \\
\text { validity })\end{array}$ & $1 / 1$ & $1 / 1$ & $1 / 1$ \\
\hline $\begin{array}{l}\text { Separation of infringement and } \\
\text { validity }\end{array}$ & Yes & No & No & No \\
\hline Preliminary injunctions & Yes & Yes & Yes & Yes \\
\hline Cross-border enforcement & No & No & Yes & No \\
\hline $\begin{array}{l}\text { Average cost range (in } \\
\text { thousand EUR) }\end{array}$ & $80-200$ & $50-200$ & $60-200$ & $2000-4000$ \\
\hline Fee shifting & Partly & Partly & $\begin{array}{l}\text { Full (barely before } \\
\text { '07) }\end{array}$ & $\begin{array}{l}\text { Full (issue- } \\
\text { based) }\end{array}$ \\
\hline Utility models & Yes & No & No & No \\
\hline
\end{tabular}

A recent UK decision-Actavis Group HF v Eli Lilly \& Co [2012] EWHC 3316 (Pat)-has allowed for very limited cross-border enforcement of patents, but this was largely not applicable to cases decided during our case filing period 2000-2008

In France there is something called a Certificate of Utility but it is not identical to a Utility Model. http:// www.wipo.int/sme/en/ip_business/utility_models/where.htm. Last visited 05 Nov 2005

challenged at the Supreme Court (formerly the House of Lords). Once again, leave must be given for appeal to the Supreme Court (SC), either by the CA or the SC itself. $^{17}$

As noted above, the validity of an EP can be challenged by filing an opposition before the EPO. In addition, the UK Intellectual Property Office (UK IPO) has a procedure to revoke UK national patents (GBs), e.g., via its patent opinion service. ${ }^{18}$

In the UK there is a combined system of filing infringement and revocation claims at the same court. This means that the PCC (now, the IPEC) and the PHC have jurisdiction to determine both infringement and the validity of a UK national patent (GB) or the UK-validated part of a European patent (EP).

The jurisdiction of the PCC and PHC to determine patent validity is independent of the question of whether the deadlines for opposition against an EP have or have not lapsed and/or whether opposition proceedings are pending. However, the courts can stay the proceedings until the EPO has decided about an opposition. In the past, the PHC only rarely granted a stay pending EPO proceedings, but a recent decision of the UK Supreme Court has led to a partial revision of this policy. ${ }^{19}$

\footnotetext{
17 According to the Judicial and Court Statistics 2008, the number of IP related cases heard by the House of Lords/Supreme Court is typically negligible-there were none in 2006, there was only 1 out of 45 total cases heard in 2007, and only 1 out of 74 total cases heard in 2008 (Judicial and Court Statistics 2008).

18 See https://www.gov.uk/guidance/opinions-resolving-patent-disputes (last visited 05 Nov 2015).

19 See Virgin Atlantic Airways Ltd v Zodiac Seats UK Ltd (formerly known as Contour Aerospace Ltd) [2013] UKSC 46.
} 
Proceedings available to Patentee

Proceedings available to Alleged Infringer

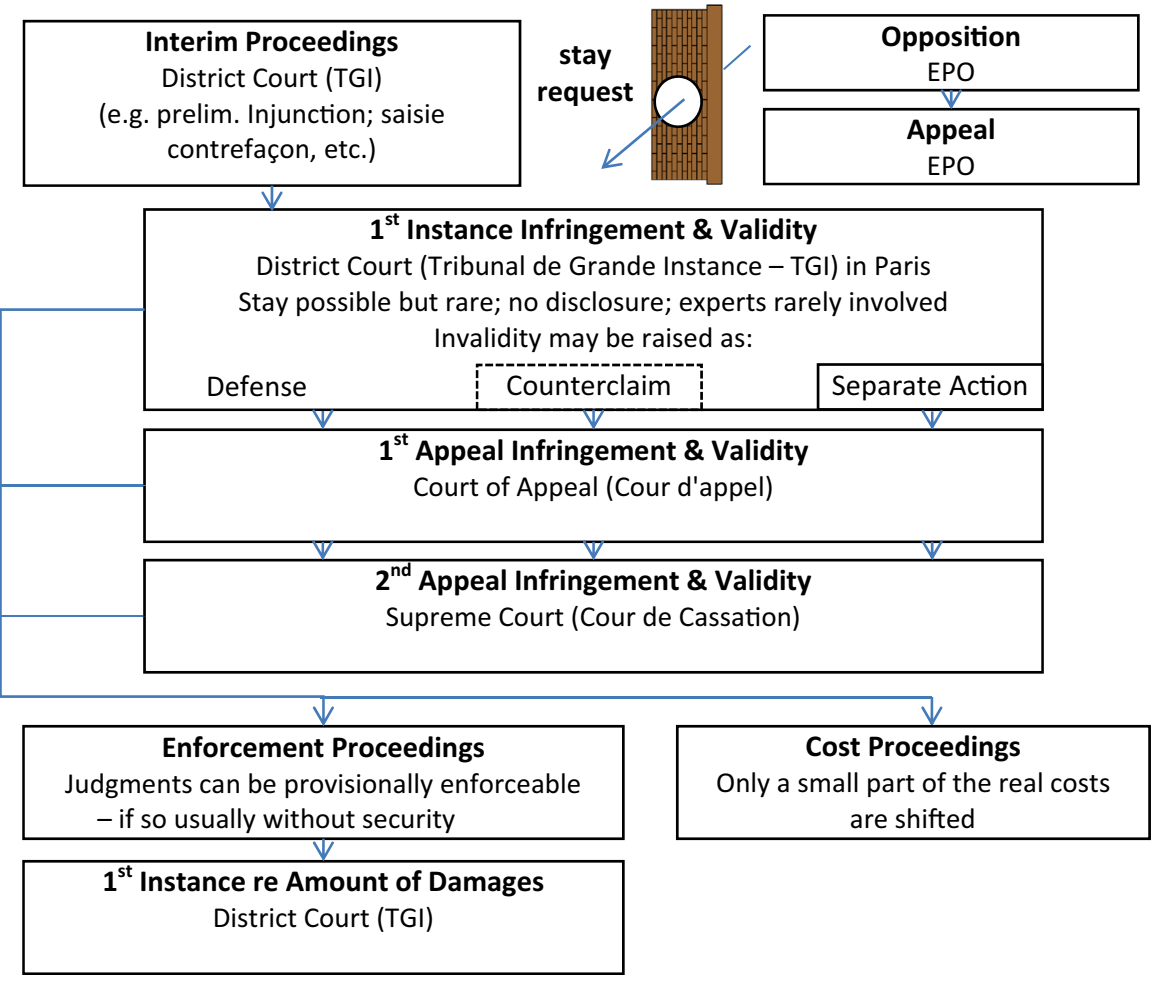

Fig. 3 Overview of the patent litigation system in France

\subsection{France}

The patent litigation system in France is illustrated in Fig. 3. Until June 2008, there were 10 specialised courts (Tribunaux de Grande Instance-TGI) that dealt with actions involving patent infringement and the related issue of unfair competition. Out of the 10 courts that heard patent cases until mid-2008, only two (Paris and Lyon) had specialist patent judges. These two courts, together with the court in Lille, heard the vast majority of patent actions. ${ }^{20}$ The decisions of the TGIs could be appealed before the Court of Appeal (Cour d'Appel—CdA) which had the territorial jurisdiction for the relevant TGI. ${ }^{21}$ Since 2009 the TGI in Paris has the exclusive jurisdiction for all patent cases. ${ }^{22}$ Therefore, the only competent $\mathrm{CdA}$ is now the $\mathrm{CdA}$ in Paris. The decisions of a CdA can be appealed to the Supreme Court (Cour de Cassation-CdC). ${ }^{23}$

\footnotetext{
${ }^{20}$ See Ladas and Perry (2002) and Véron (2002, p. 388).

21 See Art. R 211-1 COJ.

22 See Art. L615-17 CPI and D211-6 COJ (decree dated 9th October 2009).

23 See Art. L 111-2 COJ.
} 
There is no opposition procedure to challenge French national patents at the Institut National de la Propriété Industrielle (INPI). ${ }^{24}$ The validity of French national patents and French-validated EPs can be examined by the TGI. Like in the $\mathrm{UK}$, there is no German-style specialized, separate court for revocation actions. If infringement proceedings are already pending, invalidity can be raised as a counterclaim or defense. ${ }^{25}$ However, the validity of FR patents and the French part of an EP can also be challenged in an isolated revocation action. ${ }^{26}$ However, standalone actions for revocation are very rare in France (Véron 2010). In most cases $(>90 \%)$ the validity issues are raised as a counterclaim for revocation. ${ }^{27}$ The courts have wide discretion to stay proceedings during a pending opposition at the EPO, but do so only if they find that the likelihood of success of the opposition is high and if the balance of the party's interests does not contradict a stay. ${ }^{28}$

\subsection{The Netherlands}

Figure 4 shows the Dutch patent litigation system schematically. Since 1987 The Netherlands has had a highly centralized system of patent enforcement. ${ }^{29}$ All patent matters must be brought before the courts in The Hague (s'Gravenhage), which have exclusive jurisdiction. ${ }^{30}$ First instance actions must be filed at the patent chamber of the district court (Rechtbank) and an appeal may be taken to the patent chamber of the court of appeal (Gerechtshof). Appeal decisions may be subject to final judgment at the Supreme Court (Hoge Raad).

There is no opposition procedure for Dutch national patents comparable with that of the EPO for EPs. In Dutch legal actions, infringement and validity of Dutch national patents and Dutch-validated EPs are dealt with by the same court, either in the same proceedings (when invalidity is raised as a means of defense), in separate but simultaneous proceedings (a revocation action by way of a counterclaim), or in separate revocation proceedings. ${ }^{31}$

The validity of a Dutch national patent can always be challenged in court. ${ }^{32}$ By contrast, if the validity of the Dutch part of a European patent is challenged in the Dutch courts while opposition proceedings are pending, the revocation proceedings

\footnotetext{
24 See Véron (2002, p. 387).

25 There is an important difference between the defense for revocation and the counterclaim for revocation. A counterclaim constitutes a claim of the defendant and results, when it is admitted, in the revocation of the patent. The defense for revocation is only a defense means and results only in the dismissal of the claim for infringement and the patent remains in force, see Véron (2002, p. 387) for the details.

26 See Art. L613-25 and L614-12 CPI.

27 See Véron (2002, p. 387), who estimates inter alia that only $5 \%$ of the actions are isolated actions.

28 See Hogan Lovells (2013).

29 Before 1987 all 19 district courts had the jurisdiction to hear patent infringement cases, see Brinkhof (2000, p. 707).

30 See Sec. 80 DPA.

31 See CMS (2013, p. 61).

32 See Art. 75 DPA.
} 
Proceedings available to Patentee

Proceedings available to Alleged Infringer

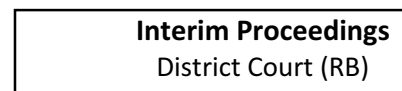

(e.g. prelim. injunction; search and seizure of evidence)

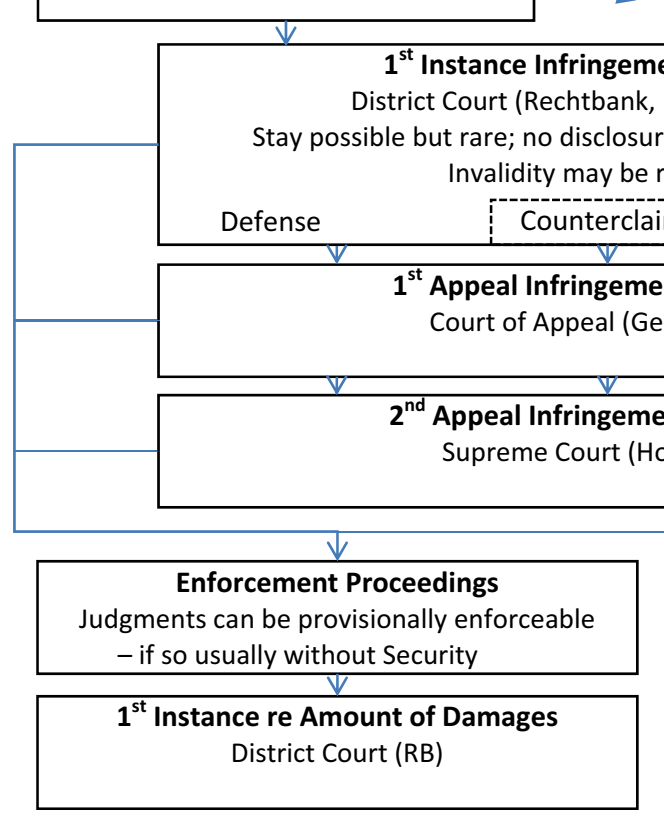

Fig. 4 Overview of the patent litigation system in The Netherlands

are usually stayed. However, Dutch infringement proceedings are normally not stayed while an EPO opposition proceeding is pending. ${ }^{33}$

\subsection{Differences across jurisdictions}

Having described the characteristics of the different enforcement systems, we highlight in this section a number of differences across the four systems which have important effects on litigation behavior and hence the data described in the next section. Table 1 summarizes the main differences across the jurisdictions, which are explained in more detail below.

\subsubsection{Bifurcation}

A major difference between the four legal systems is that Germany uses a bifurcated system. This is not the case in any of the other three legal systems covered by our analysis.

\footnotetext{
${ }^{33}$ See Swens and Reijns (2011, p. 4).
} 
Due to the existence of bifurcation it is possible for a regional court in Germany to grant an injunction against a potential infringer of a patent which is later found to be invalid by the EPO, DPMA or the Federal Patent Court. ${ }^{34}$ Another potential issue is that regional courts, which decide on infringement, and the Federal Patent Court that decides on validity construct claims independently of each other. This might lead to inconsistent claim constructions in the infringement and revocation procedures. This is often referred to as the Angora cat problem where the patentee applies the broadest possible interpretation of the patent claims in infringement procedures (a fluffy, blow-dried cat) and the narrowest possible interpretation in revocation proceedings (a wet, rolled-up cat). This creates the problem that an infringement court might issue an injunction against a defendant on the basis of a broad claim construction which would inevitably lead to the invalidation in view of a certain piece of prior art. At the Federal Patent court, in contrast, the patentee uses the narrow interpretation, which leads to the patent being upheld. Furthermore, there could be fewer counterclaims for revocation in the bifurcated system as costs involved in engaging in an additional, separate court action may be prohibitive, especially for smaller, resource-constrained companies. There is also the possibility that an alleged infringer drops the validity challenge as soon as the LG confirms that no infringement has taken place. Since a successful invalidity challenge produces positive externalities for other companies, in particular the challenger's competitors that might also infringe the patent, the challenger has strong incentives to drop the challenge once its own situation has been clarified by the infringement court.

On the other hand, exclusive jurisdiction on patent validity offers the advantage of specialization. The Federal Patent Court charged with validity cases can train and deploy technical judges and accumulate experience specifically in the assessment of patent validity, facilitating coherent and well-founded claim construction and therefore increase legal certainty regarding the validity of patents. Since separate patent revocation proceedings increase the costs and risks for the alleged infringer, the separation of infringement and revocation procedures may lead alleged infringers to refrain from filing a revocation action if they have relatively low chances of success. Moreover, the strong presumption of validity, which puts considerable faith in the examination of the patent offices, could allow for a fast assessment of infringement claims, because validity does not need to be assessed simultaneously.

\subsubsection{Number of competent courts}

Another major difference between the legal systems is that in Germany several regional courts are competent to hear patent infringement cases; by contrast the UK, France (since 2009) and The Netherlands all make use of centralized systems for patent litigation.

This means that claimants in Germany can usually choose among several regional courts where to file an infringement claim. In the UK, depending on the

\footnotetext{
34 For more discussion and empirical evidence on this "invalid but infringed" scenario see Cremers et al. (2014).
} 
size and value of the claim, the filing will typically be either at the PCC (IPEC) or the PHC (both are located in London); while in France patent cases must be taken to the TGI in Paris; and in The Netherlands first instance actions must be filed at the patent chamber of the district court in The Hague. In practice, this difference is mitigated somewhat by the strong concentration of cases in Germany in three out of the twelve competent courts-Düsseldorf, Munich and Mannheim.

\subsubsection{Duration of the proceedings}

In Germany, proceedings before the LG tend to be relatively speedy with the (first) oral hearing scheduled after 6-12 months, and judgment 1-3 months after the (second) oral hearing. Revocation decisions by the BPatG take usually at least 18 months after the filing of the revocation suit before the BPatG. In this respect it is important to recall that revocation actions are usually reactive actions and therefore filed after the infringement action has been initiated. Similarly, in The Netherlands proceedings are comparatively speedy-both Germany and The Netherlands follow a paper-based litigation procedure, with short oral hearings.

Regarding time limits, in the UK first instance cases filed before the PHC often take 12 months to reach full trial, but urgent cases can sometimes be heard within 6 months. Trial hearings are lengthy due to the presence of oral arguments and cross-examination, and trials can last from several days to a number of weeks. The first instance PHC judgment will usually be handed down within 2-12 weeks of the trial. Therefore, there is a typical overall length of around 12-14 months from filing to judgment, though complex cases can take longer. In France, first instance actions take on average about 18-24 months from claim to judgment.

\subsubsection{Preliminary injunctions}

In Germany preliminary proceedings are rare in patent cases due to the speed of the normal infringement proceedings and the strict requirements for granting preliminary relief. Instead, permanent injunctions can be granted by the LG based exclusively on an assessment of the infringement claims. As noted above with regard to bifurcation, if the LG does not stay the infringement proceedings, the claim for injunctive relief is granted about a year before the question of validity is even considered by the Federal Patent Court.

In France, preliminary proceedings-the saisie-contrefaçon-are commonly used to initiate infringement actions. As noted above, the court in France may order the seizure of the defendant's goods within a few weeks of the action. Nevertheless, preliminary injunctions tend to be rare in France. This is also the case in the litigation system of the UK (England and Wales), where preliminary injunctions are relatively uncommon in patent cases. This might be partly explained by the practice of "clearing the way" - in the UK it is expected that a potential infringer should attempt to "clear the way" before bringing products to market that could potentially infringe a competitor's patent(s) by proactively seeking revocation of the competitor's patent(s), or alternatively, to seek a declaration of non-infringement. If they do so, they can avoid the possibility of an interim injunction being granted 
against them if the competitor decides to take patent infringement proceedings. ${ }^{35}$ If a potential infringer does not do this, it is more likely that the PHC will grant a preliminary injunction preventing the sale of the potentially infringing product upon the commencement of infringement proceedings. In The Netherlands, the Kort Geding, a system of preliminary relief proceedings, comes into play. A preliminary injunction to halt infringing activities may be obtained within two weeks after filing a case. It also used to be commonplace in The Netherlands for a cross-border injunction to be granted with respect to infringement actions.

\subsubsection{Costs and fee shifting}

Since German infringement proceedings do not foresee extensive pre-trial disclosure of information and only short hearings usually without experts, proceedings are usually considerably less expensive than in other jurisdictions even if the same hourly rates for attorneys apply. Practitioners estimate the average costs to range between EUR 40,000 and EUR 100,000 per party. ${ }^{36}$ The attorney fees are calculated according to a formula based on the estimated value of the dispute. ${ }^{37}$ These fees are the basis for the reimbursement of costs which the winner of a case can demand from the loser. However, the attorney fees do not represent the true legal costs, but only a lower bound to which the attorney is entitled. Clients and their attorneys often agree to payment schemes based on an hourly rate which leads to attorney costs well above the legal fees. As a result, the costs are often not fully shifted to the loser.

In the UK, practitioners estimate the costs of a case which reaches trial to be at GBP 1.5 million for each side. ${ }^{38}$ These estimates are supported by the research undertaken by Helmers and McDonagh (2013b) which show costs often ranging between GBP 1 million and GBP 6 million (encompassing the costs from both sides) for cases initiated during 2000-2008. ${ }^{39}$ The main reasons for the relatively high costs are the disclosure requirement, the length of trial, the requirements for the carrying out of experiments and the cross-examination of expert witnesses. The loser pays costs system applies in this context-the losing litigant must pay not only his own costs, but also the costs of the other side. However, it is also important to note that such costs are allocated via an issue-based approach; depending on who lost which issue in the case, and taking into account how much court time the issue took to resolve, the court allocates the costs to each side on a proportionate basis

\footnotetext{
35 Jacob J. (as he then was) noted: "Where litigation is bound to ensue if the defendant introduces his product he can avoid all the problems of an interim injunction if he clears the way first. That is what the procedures for revocation and declaration of non-infringement are for." -SmithKlineBeecham v Apotex [2002] EWHC 2556(Pat) at para. 68.

36 See CMS (2013, p. 47) and Bardehle (2013, p. 12).

37 The value in dispute (VID) is set by the court and can range from EUR 300 to EUR 30 Million (see $\S$ 39 (1) Litigation cost act (GKG)). Practitioners estimate the average value in dispute to be typically between EUR 500,000 and EUR 5 million, see Bardehle (2013, p. 12).

38 See Freshfields (2011, p. 8).

39 See Helmers and McDonagh (2013b, p. 384).
} 
also taking into consideration whether costs incurred were reasonable under the circumstances of the case. ${ }^{40}$

In French proceedings, the involvement of the court is entirely free. ${ }^{41}$ Most of the time, the attorney fees are calculated according to an hourly rate agreed with the client. The usual costs of the proceedings are estimated to range between EUR 50,000 and EUR 200,000. ${ }^{42}$ In principle, the French system shifts the costs to the loser. ${ }^{43}$ However, in practice the fees are shifted only to a very limited extent. For example, practitioners estimate that the sum of the granted litigation costs are on average between EUR 200 and EUR 300 and the granted lawyer's fees are on average around EUR 3000. ${ }^{44}$

Patent litigation in The Netherlands is estimated to cost on average between EUR 60,000 and EUR 200,000. ${ }^{45}$ In principle, also The Netherlands shift the costs to the loser. Before the enforcement directive was implemented in 2007, the courts had usually shifted only a small amount of the fees. ${ }^{46}$ However, since then full costs may be shifted. ${ }^{47}$

There is an important theoretical literature that explores the importance of the allocation of costs among litigants (Reinganum and Wilde 1986; Spier 1992). The theoretical literature distinguishes between the American (no fee shifting) and British (full fee shifting) rule to find that in the presence of asymmetric information about the likelihood that the claimant prevails at trial, fee shifting encourages out-of court settlements (Spier 1992). The German and French systems could be considered as intermediate systems, shifting part of the costs from the winning to the losing party. In reality, however, in the UK costs are allocated on a per-item basis, which means that in practice often costs are not fully shifted from the winning to the losing party (Helmers and McDonagh 2013b).

\subsubsection{Utility models}

In contrast to the other three jurisdictions, the German Patent and Trademark Office also grants utility models (Gebrauchsmuster). The legal remedies available to owners of utility models are the same as those available to patentees. Utility models differ from patents above all in that they are not subject to substantive examination by the patent office. As a result, they are registered within only a few months of filing. At the same time, in case the validity of a utility model is challenged in court, the burden of proof is on the owner of the utility model to show that the claims are

\footnotetext{
${ }_{40}$ For more discussion see Helmers and McDonagh (2013b, pp. 387-392).

41 See Art. L. 111-2 Code de l'organisation judiciaire (COJ); Véron (2002, p. 400).

42 See van Pottelsberghe de la Potterie (2009).

43 See Art. 696 and 700 CPC, for details see Reiman (2012, p. 143 seq).

44 See Véron (2002, p. 401).

45 See Harhoff (2009, p. 31).

46 See Brinkhof (2000, p. 721).

47 See $\S 1019$ h Rv and Danisco A/S v. Novozymes A/S, Court of Appeal The Hague, 26 February 2013, Case no. 200.094.921/01, Dutch version available at http://www.eplawpatentblog.com/eplaw/2013/03/nldanisco-v-novozymes-litigation-costs-post-bericap.html (last visited 05 Nov 2015) and Land (2010).
} 
valid. Utility models are restricted to product claims and their statutory life time is only 10 years. The existence of utility models in Germany makes a comparison of case counts across jurisdictions more complicated. Often utility models are used as a substitute for invention patents in Germany and they can be part of an international patent family. Inventions may also be protected by a combination of utility and invention patents. Such a strategy is particularly attractive to applicants if they want to seek an injunction relatively early.

\section{Data collection}

The case data were collected from court records in the four countries. We collected data for cases filed during the period 2000-2008. This captures relatively recent cases and, given the lengthy nature of patent cases (especially where appeals are heard), we avoid having a large number of pending cases in the dataset. There were some important differences in the way we collected the data in the various jurisdictions-the methods used are briefly described below.

\subsection{Germany}

Due to the existence of the bifurcated system, the data on infringement and revocation cases had to be collected separately.

Regional courts which hear infringement cases publish few court records and do not systematically list cases and types of cases heard before the chambers. Moreover, there are practically no digital archives of case-related data at the courts. Comprehensive summary statistics are only available for the BPatG and the BGH. ${ }^{48}$ To cover the largest number of court cases possible with the resources available to us, we chose the three most important (in terms of the number of patent cases) courts of the 12 existing regional patent courts in Germany: Düsseldorf, Mannheim, and Munich. ${ }^{49}$ The identification of the relevant patent cases-including both invention patents and utility models-among other IP related cases such as trademark or design cases, inventor employee issues and pure licensing issues, was done by screening all cover pages of written case files in Mannheim and Düsseldorf. In Munich, the identification of patent cases was done based on lists supplied by judges. The relevant information on the cases is stored in paper format in the court dockets. That means all case-related information had to be collected manually for each individual case by physically accessing the court dockets at each regional court.

We started the data collection in Mannheim in spring 2010. We proceeded with Munich in December 2010 and Düsseldorf in December 2011. On average, seven trainee attorneys were hired in each court location to collect the data from court files and to digitize the information. We estimate that our data on patent infringement

\footnotetext{
${ }^{48}$ The statistics of the BGH can be accessed at: http://www.bundesgerichtshof.de/DE/BGH/Statistik/ statistik_node.html; the statistics for the BPatG are published in the journal Blatt für Patent-, Muster-und Zeichenwesen.

49 See Ann (2009).
} 
actions before the German courts in Mannheim, Düsseldorf, and Munich cover around $80 \%$ of all patent related cases in Germany during the period 2000-2008. ${ }^{50}$

We also have information on revocation proceedings before the BPatG and its appeal court, the BGH. Both courts publish all decisions on validity since 2000 on their websites. Apart from these judgments, we also obtained information on withdrawn revocation actions from the German Patent and Trademark Office (DPMA). The available data for revocation actions are complete for the period from 2000 to 2008.

\subsection{UK}

We collected data on all court cases filed between 2000 and 2008 at the PHC, the Court of Appeal and the House of Lords/Supreme Court which involved a patent. ${ }^{51}$ We exclude all cases that represent an appeal to an administrative decision taken by the $U K I P O .^{52}$

In contrast to Germany, court records in patent cases are generally, albeit selectively, published. We therefore collected the data on court cases at the PHC from a range of online sources. Our starting point was the Patents Court Diary which, in principle, lists all cases which are scheduled for a hearing or an application including, for example, a case management conference. ${ }^{53}$ This means the diary contains all cases which have been scheduled for a hearing.

It is important to emphasize that any case which settles after filing, but before it is scheduled for a hearing, ${ }^{54}$ including a CMC, would not appear on the diary, and therefore does not form part of our dataset. Nevertheless, cases which settle after they have been scheduled for a hearing, regardless of whether the hearing eventually took place, are listed, and therefore form part of our study. We used the information from the diary to search for court records on the website of the British and Irish Legal Information Institute, ${ }^{55}$ the case database of Lexis Nexis, ${ }^{56}$ as well as Thomson Reuters's Westlaw database. ${ }^{57}$ Nonetheless, these sources did not offer any records for a number of cases (presumably mostly those settled at an early stage). For these

\footnotetext{
50 This estimation is supported by Harhoff (2009, p. 26). Having information from all regional courts for 2009 , Klos (2010, p. 72 seq.) numbers suggest a share for the three regional courts of merely $70 \%$ of total court cases. However, Klos (2010, p. 72 seq.) includes all patent related disputes while we focus on infringement cases only. In line with Stauder (1983), we assume that this divergence is due to a varying distribution of cases according to subject-matter among courts.

51 We exclude cases heard at the PHC which did not involve a patent e.g. designs cases.

52 We also have data on court cases heard before the PCC (Central London County Court) which we obtained from the UK IPO. Because the information on cases at the PCC had to be collected directly from the PCC, we only have detailed information on cases heard in 2007 and 2008. Moreover, the data were anonymized due to confidentiality restrictions. For this reason, we exclude the PCC data in this analysiswith the exception of Appendix Table 12 (for more details see Helmers and McDonagh 2013a).

53 See http://www.hmcourts-service.gov.uk/cms/list_patents_diary.htm.

54 Essentially, these are cases which settle after filing but before any court involvement.

55 See http://www.bailii.org (last visited 05 Nov 2015).

56 See http://www.lexisnexis.co.uk. (last visited 05 Nov 2015).

57 See http://www.westlaw.co.uk. (last visited 05 Nov 2015).
} 
cases we searched additional sources, such as media websites, blogs or the websites of legal representatives for information.

While our datasets represent the most comprehensive database gathered so far on the subject of patent litigation in the UK, ${ }^{58}$ three caveats are in order. First, relying on the court diary means that we only observe cases that have not only been filed to the court, but which were also allowed to proceed at least to the case management stage. There is no information available on the number of cases which are dropped between the serving of the claim form and the case appearing on the diary. The number of cases within our dataset is comparable with the official UK Ministry of Justice (MoJ) statistics on case numbers at the PHC, once the cases which do not form part of our study, i.e., appeals from the IPO and the non-patent PHC cases, are removed. ${ }^{59}$ Secondly, since we had to assemble the information with regard to each court case, often relying on different sources, the available court records are in many cases incomplete. ${ }^{60}$ A particular concern relates to the patent numbers of litigated patents, because even when a case is decided through judgment the published judgment may not identify the disputed patents. This means that we have patent numbers only for 165 out of the 256 patent cases between 2000 and 2008 . Thirdly, with regard to the counting of UK cases, for the purpose of clarity it is important to note that where a number of separately filed cases involving the same parties were joined and heard together we considered these cases to be "one case."

\subsection{France}

The French dataset contains patent cases at the Court of Paris in first and second instance (Tribunal de Grande Instance-TGI and Cour d'Appel). While Paris has exclusive jurisdiction over patent disputes in France since 2009, ten courts were sharing jurisdiction over patent disputes during the period 2000-2008 covered by our data. According to Véron (2002), the TGI in Paris accounted historically for around $60 \%$ of all patent cases in the country. ${ }^{61}$

Our data for France originate from a private company, Darts-IP, which specializes in IP case law. Darts-IP was helpful mainly for two reasons: first, the TGI is not specialized in patent cases and court registers do not record patent cases

\footnotetext{
58 The data used by Moss et al. (2010) only contain court cases between January 2008 and August 2009 heard by the Patents County Court, the Patents Court, the Court of Appeal, and the House of Lords.

59 For the PHC in 2007 the MoJ lists 55 actions and for 2008 it lists 61 actions. See Ministry of Justice, Judicial and Court Statistics 2007 (The Stationery Office, September 2008) and Judicial and Court Statistics 2008 (The Stationery Office, September 2009); accessible at http://www.official-documents. gov.uk/document/cm76/7697/7697.pdf and http://www.official-documents.gov.uk/document/cm74/7467/ 7467.pdf. Recently we examined the paper PHC case files at the court. The physical PHC files are mixed in with regular Chancery Division files, which makes the case-counting extremely challenging and timeconsuming. Nevertheless, counting records for cases filed at the PHC in 2007 revealed that there were an additional seven cases filed which did not appear in the diary or elsewhere in the online records available to us.

${ }^{60}$ For example, while we may have the judgment of the PHC, we may not have records for all preceding applications.

61 Véron (2002, p. 388) notes that the distribution of patent cases among the ten courts was highly skewed as seven out of the ten courts dealt with less than 15 cases per year.
} 
in a specific way that would allow filtering them from the huge collections of all cases filed at the court. Darts-IP collects decisions from all cases and manually identifies the nature of the main action, allowing us to filter patent cases. Similar to the UK, information can be obtained from published court records because in the French litigation system, as soon as an action is filed at a given TGI, the court quickly issues an official document called an Ordonnance de mise en état, which summarizes the claims filed by the claimant and sets the calendar for the case. These documents reveal most of the features of the case (names of the parties, patent numbers, filing dates, etc.). Darts-IP obtains data also from the French patent office (INPI) and Véron and Associés (an established law firm) that also collect data on patent cases at the Paris court. Secondly, Darts-IP analyzes court records and manually retrieves the information on the litigating parties, patent numbers, filing and judgment dates, and some other features of the case.

We complemented the Darts-IP data with additional variables that we extracted manually by a team of four trainee attorneys, including the type of first action, outcomes, appeals, etc. As in the case of the UK, we then exclude appeals to administrative decisions of the INPI (the Court of Paris also has jurisdiction as an appellate level to decisions of the French patent office, but this is not the focus of our dataset). Once the analysis at the individual decision level was completed, we grouped all court records into unique cases. This grouping is done in several steps: (1) Darts-IP links every decision to its antecedent, forming a chain of decisions relating to the same case (2) we use case references attached to each decision to identify further decisions belonging to the same case that were not linked by Darts-IP, (3) we look for all dockets that have at least 2 parties and 1 patent family in common and manually check whether these belong to the same action, in which case we merge them into a single case record. This aggregation is presumably the main reason why the figures presented in Table 3 below differ significantly from the case counts in Véron (2010) and Graham and van Zeebroeck (2014) for the TGI Paris for the same time period. Caselevel variables are then computed or aggregated based on decision-level variables. Settlements are identified through the issuance of Désistments or Révocation orders, in which the court acknowledges that the charges are dropped by the claimant.

\subsection{The Netherlands}

The dataset for The Netherlands was collected and constructed in the same way as the French dataset, with two main differences. First, one court has exclusive jurisdiction over all patent cases in The Netherlands throughout our period of interest: the Court of The Hague (s'Gravenhage). Second, in contrast to France, in the Dutch system there is almost no automatic release of court records once a case is filed (e.g. ordonnances de mise en état). Neither is there a court diary as in the case of the PHC in England and Wales. As a result, our dataset may miss a substantial number of cases that were settled before any court decision was made, and may fail to identify some settlements as the court does not publish anything once a case is dismissed. However, Graham and van Zeebroeck (2014), quoting practitioners in The Netherlands, indicate that only an estimated 10-15\% of patent cases are typically settled each year in the country. 


\subsection{Identification of cases litigated in multiple jurisdictions}

To identify parallel cases, we proceeded as follows. We used all available patent numbers of court cases in all four countries and constructed their patent families to obtain German, UK, ${ }^{62}$ Dutch, French, as well as EPO equivalents. ${ }^{63}$

We then matched patent families across the four jurisdictions to identify patents litigated in several jurisdictions. If we found a patent (family) to be involved in disputes in more than one jurisdiction, we also cross-checked litigating parties' names to ensure the assignee is the same (either as claimant or defendant). ${ }^{64}$ For example, we considered a case where patent $\mathrm{X}$ is litigated in jurisdiction $\mathrm{Y}$ by parties $\mathrm{A}$ and $\mathrm{B}$ to be parallel to a case in jurisdiction $\mathrm{Z}$ where patent $\mathrm{X}$ is litigated by parties $\mathrm{A}$ and $\mathrm{B}$.

The search for parallel cases was partly facilitated by data that we collected from UK court records that provided information on the existence of parallel cases outside of the UK, including Germany, France, and The Netherlands. This information is only available when judges refer explicitly to parallel cases in their judgments. Hence, this information is far from complete. It nevertheless provides additional information that we used to assist in the identification of parallel cases.

\subsection{Case counts}

Counting court cases and comparing case counts across jurisdictions is inevitably a challenge because of the differences in litigation systems described above - notably bifurcation-as well as the various procedural differences. However, missing data pose additional challenges. To allow for a meaningful comparison, we present our case counts using a number of different methods of counting cases while simultaneously making use of different assumptions about the missing information. Table 2 summarizes the different ways in which we counted cases. In Table 2, the presence of gray shaded cells indicates that the data necessary to adjust case counts is available in a given jurisdiction, whereas the presence of white cells means that the data are not available. Black cells mean the adjustment is not applicable in a given jurisdiction.

For each jurisdiction, we counted all available patent cases regardless of the underlying claim e.g. infringement, invalidity, ownership dispute etc. Nevertheless, since we are primarily interested in infringement and revocation (invalidity) cases, we also computed case counts limited to those claims. ${ }^{65}$ Further, we adjusted the number of cases for missing data, primarily with respect to courts not covered by our data collection in each jurisdiction. In Germany, this concerned nine LGs; in the

\footnotetext{
62 Note that we do not have patent data for all cases (for example in the case of the UK, we have data for only $65 \%$ of all cases).

63 We use the extended INPADOC patent family definition in Patstat.

64 For this purpose, we harmonize the names of litigating parties according to established string cleaning methods. We convert all strings to uppercase, standardize characters to the ISO basic Latin alphabet and remove punctuation marks. We further remove legal forms and generic suffixes to account for domestic subsidiaries of multinational corporations. We complement the automated matching of litigating parties' names with extensive manual checks.

65 We dropped other claims, such as employee inventions, entitlement, etc.
} 
Table 2 Different ways to count cases

\begin{tabular}{|c|c|c|c|c|}
\hline Adjustment & $\mathrm{DE}$ & UK & FR & NL \\
\hline \multicolumn{5}{|l|}{ Only infringement and revocation claims } \\
\hline \multicolumn{5}{|l|}{ Missing cases (courts not covered)* } \\
\hline \multicolumn{5}{|l|}{ Only invention patents* } \\
\hline \multicolumn{5}{|l|}{ Cases counted once per patent ${ }^{*}$} \\
\hline \multicolumn{5}{|l|}{ Consolidated at case-level $^{\Re}$} \\
\hline \multicolumn{5}{|l|}{ Eliminate early settled cases ${ }^{\star}$} \\
\hline \multicolumn{5}{|l|}{$\begin{array}{l}\text { Count counterclaims for revocation and } \\
\text { infringement as separate cases }\end{array}$} \\
\hline & \multicolumn{4}{|c|}{ applicable } \\
\hline & & \multicolumn{3}{|c|}{ not applicable } \\
\hline & & \multicolumn{3}{|c|}{ data not available } \\
\hline
\end{tabular}

The table shows the different changes to the ways in which we count court cases across jurisdictions. Some adjustments are not applicable to all jurisdictions and for some adjustments no data is available in a given jurisdiction

* 9 LGs not covered in DE, PCC not covered in UK, 9 TGIs not covered in FR

* Excludes utility models for DE

- Use average number of patents for UK where for $35 \%$ of cases patents are not available $\Re$ For UK cases available only at the consolidated level

- In UK cases settled before CMC scheduled not covered-exclude cases in DE that settled within 6 weeks after receipt of claim

UK this concerned certain years of the PCC (2000-2006); and in France 9 TGIs. ${ }^{66}$ Since the German data included utility models, we also provide case counts excluding utility models. ${ }^{67}$

Cases that involve several patents are often split by the courts in Germany so that there are separate case numbers for each patent involved in the case. One way of accounting for this is to assume that one patent corresponds to one case. Hence, we count each case once for each patent that it concerns. Alternatively, a way to adjust the data to take account of this problem is to consolidate all actions that presumably belong to the same case. Consolidation in this context includes taking account of different actions that occur at the same time (e.g. where there are different case numbers for each patent in a case that involves several patents but essentially the same facts/merits) as well as different actions that take place over time within the same overall case (e.g. an

\footnotetext{
66 No such adjustment is necessary for the Netherlands as there is only a single court that hears patent cases.

${ }^{67}$ Note that utility models are widely used in Germany and can also be used as substitutes for invention patents. Hence, it is possible that an invention patent covers a given invention in France whereas the same invention is covered by a utility model in Germany. For more discussion see Sect. 2.5.6.
} 
application for a preliminary injunction and the final arguments/judgment). Thus, we consolidated the data to account for the possibility that several separate actions are recorded - but in reality they form part of the same case.

Furthermore, as noted above, since we collected the data for the UK principally from the court diary, cases that settle before they are scheduled for a CMC, or a preliminary hearing, are not covered by our data. To make the UK and German data comparable, we dropped from our comparison all cases in Germany that also settled very early on, i.e., before the court took action on the case.

Finally, within the German bifurcated system infringement and revocation cases constitute separate cases even when the revocation case is a direct reaction to the infringement case (or vice versa). One way to replicate this set-up in a nonbifurcated system is to count counterclaims for both revocation and infringement as separate cases. These data are available only for the UK, and thus we make this comparison of German cases only with UK data.

\section{Comparison of patent litigation in Germany, the UK, France and The Netherlands}

This section presents the results of our analysis. We compare patent cases across Germany, the UK, France and The Netherlands.

\subsection{Case-Counts}

Table 3 shows the total of patent cases for all four jurisdictions over the period 2000-2008.

By far the largest number of cases is heard by German courts. Of the total of 6739 cases in Germany, 5121 are infringement cases heard by the three regional courts covered by our study whereas 1618 are revocation cases heard by the BPatG. ${ }^{68}$

The differences apparent in Table 3 may be partly driven by the differences in economic activity across the four jurisdictions. Table 4 shows litigation rates accounting for various macro indicators.

The overall picture does not change once we take into account the total number of patents, GDP, or total R\&D spending: Germany still displays by far the largest litigation rate regardless of how it is measured. The same is true for the UKregardless as to how litigation activity is counted, patent litigation intensity is lower in the UK than in any of the other three jurisdictions.

Table 11 in the Appendix shows case counts for Germany if we use alternative ways of defining a case (see Table 2 for an overview). If we restrict the case count to cases that claim infringement or revocation, the overall count falls by around $8 \%$ to 6220 . In contrast, if we adjust the count for the fact that we covered only the three most important regional courts, case counts jump up to 8809. If we count each case once for each patent, the number of cases increases from 6739 to 8134 (an increase

\footnotetext{
68 The drop of cases in Germany in 2002 is due to an internal decision at the regional court in Düsseldorf to remove and destroy files and only store decisions in the court archive.
} 
Table 3 Case overview

\begin{tabular}{|c|c|c|c|c|c|c|c|}
\hline \multirow{3}{*}{$\begin{array}{l}\text { Year claim } \\
\text { filed }\end{array}$} & \multicolumn{6}{|l|}{ Jurisdiction } & \multirow[t]{3}{*}{ Total } \\
\hline & \multicolumn{3}{|l|}{$\mathrm{DE}$} & \multirow[t]{2}{*}{ FR } & \multirow[t]{2}{*}{ NL } & \multirow[t]{2}{*}{ UK } & \\
\hline & $\begin{array}{l}\text { Regional courts } \\
\text { (infringement) }\end{array}$ & $\begin{array}{l}\text { BPatG } \\
\text { (revocation) }\end{array}$ & Total & & & & \\
\hline 2000 & 397 & 171 & 568 & 106 & 42 & 19 & 735 \\
\hline 2001 & 483 & 165 & 648 & 126 & 40 & 22 & 836 \\
\hline 2002 & 179 & 129 & 308 & 125 & 31 & 24 & 488 \\
\hline 2003 & 520 & 144 & 664 & 85 & 19 & 28 & 796 \\
\hline 2004 & 700 & 170 & 870 & 120 & 45 & 27 & 1062 \\
\hline 2005 & 736 & 196 & 932 & 118 & 40 & 28 & 1118 \\
\hline 2006 & 617 & 197 & 814 & 129 & 35 & 40 & 1018 \\
\hline 2007 & 795 & 195 & 990 & 106 & 36 & 31 & 1163 \\
\hline 2008 & 694 & 251 & 945 & 87 & 38 & 37 & 1107 \\
\hline Total & 5121 & 1618 & 6739 & 1002 & 326 & 256 & 8323 \\
\hline $\begin{array}{l}\text { Total } \\
\text { corrected }^{\mathrm{b}}\end{array}$ & & & 8424 & 1503 & 326 & 302 & \\
\hline
\end{tabular}

BPatG: Federal Patent Court

a Missing case files at the regional court in Düsseldorf for the year 2002

b Numbers account for the fact that not all court cases are included in our data. Approximately $25 \%$ of cases missing in DE, $50 \%$ in FR, $0 \%$ in NL, and $18 \%$ in the UK (see Appendix Tables 11, 12, 13 and 14 for annual data)

of $30 \%$ ). This underscores that not all German courts do systematically split cases according to the number of patents involved. Reducing the case count to cases that only involve invention patents means the count drops to 3700 . However, given the widespread use of utility models in Germany, often as a substitute to invention patents, looking only at invention patent cases might be too narrow a focus. Column [F] of Table 11 shows consolidated case counts and hence accounts for any potential over-counting due to case-splitting. The resulting case count is only slightly less than $70 \%$ of the original count. Finally, we drop all cases that settled very early on, essentially before the court took any action (within 42 days counting from the filing date of the claim, which is the period where parties had to file their first response to the court). This accounts for the concern that such cases might be missing from the UK case count. However, we see that the number of cases that drop out at such an early stage is very low in Germany.

Table 12 in the Appendix shows case counts for the UK after making various adjustments. When we add the available data for the PCC in 2007 and 2008, we see that the case count increases by slightly less than $20 \%$. Nevertheless, if we assume that the PCC heard on average $20 \%$ of patent cases during 2000-2008, the total case count would increase to 307 . Column [D] shows that if we counted each case once per patent at issue, we would end up with a count of 363 cases. Mimicking a 


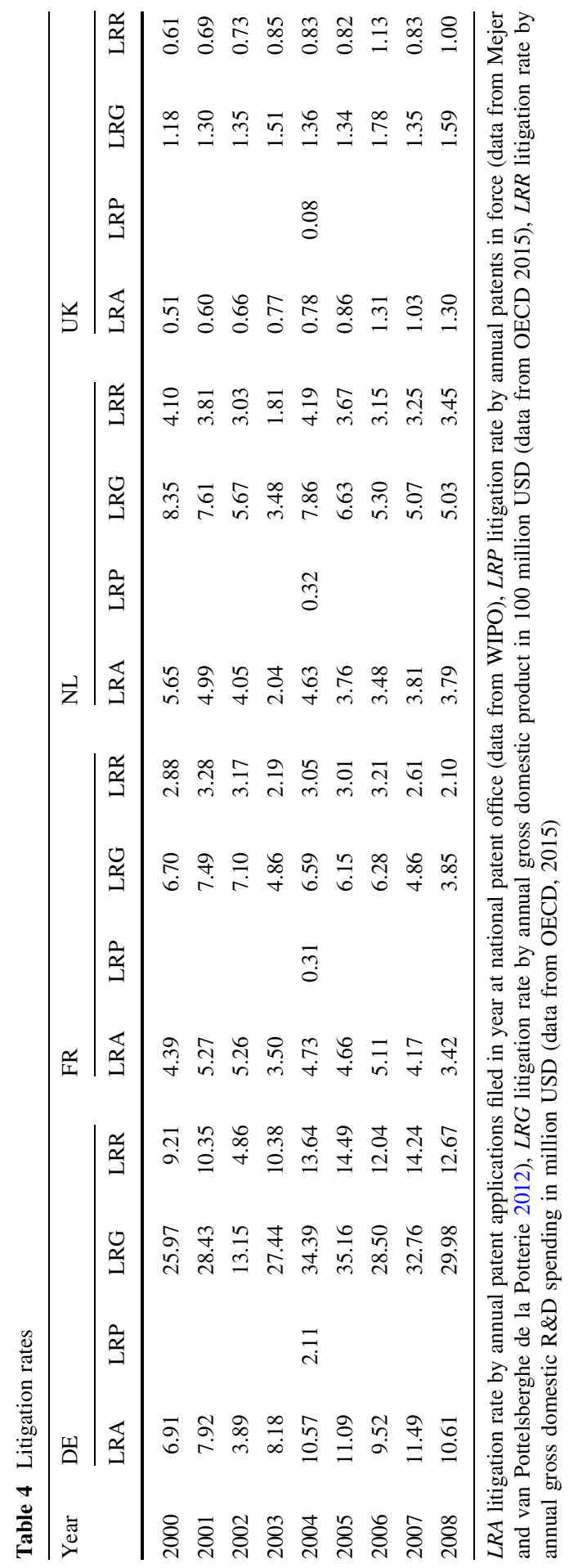


bifurcated system, Column [E] counts counterclaims for infringement and revocation as separate cases. This results in a total count of $356 .{ }^{69}$

The total caseload in France is 1002. In contrast to Germany and the UK, there is no increase in case filings over time. Due to more limited data, Table 13 in the Appendix shows only a few variations of the case count for France. Multiplying case counts by the number of patents involved (Column [D]) results only in a modest $10 \%$ increase in case counts. However, adjusting for cases that were heard by courts not covered by our data, we obtain a count of 1503 cases.

Finally, the caseload in The Netherlands with 329 cases is only slightly larger than in the UK. Since all cases are heard by a single court, in principle, no adjustment for missing cases is needed. If we count cases once for each patent at issue, the case count increases to 339 cases.

A few caveats are in order in interpreting these numbers. First, our data cover only cases that were filed between 2000 and 2008. It is possible that the case numbers have changed significantly since then. In fact, more recent data for the UK for both the PCC and the PHC suggest that case counts have increased substantially since 2000-2008, partially as a result of the reforms of the PCC (IPEC). Helmers et al. (2015) show that patent case counts at the PHC increased to 92 and 89 in 2011 and 2012 respectively. Patent case counts at the PCC increased even more dramatically from 8 in 2010 to 27 in 2011 largely as a consequence of the IPEC reforms (for detailed discussion see Helmers et al. 2015). In the case of Germany, the evidence is slightly less conclusive. Kühnen and Claessen (2013, p. 593) suggest that 475 cases have been filed at the Düsseldorf court in 2011 (compared to 437 in 2008). Whereas this is a modest increase (9\%), the increase at the LG Mannheim between 2008 and 2011 is more substantial (27\%) albeit still relatively modest in absolute terms (56 cases) in light of the large overall annual caseload in Germany. Second, and presumably more importantly, the data for France and The Netherlands are subject to important limitations. For France, we have an estimated $60 \%$ of cases overall, and in The Netherlands, the low settlement ratios at The Hague court suggests that we are missing most cases that were settled (an estimated 10-15\% of cases according to Graham and van Zeebroeck (2014)). A recent consultation of overall statistics produced by Darts- $I P^{70}$ indicate that there were about 400 firstinstance decisions per year in France in the period 2011-2014, which is twice as many cases as in our observation period (2000-2008). It is however impossible to determine the share of this doubling in counts that comes from more systematic case collection at Darts-IP and that coming from a true increase in case-loads. In contrast, in The Netherlands, counts of yearly first-instance decisions in the DartsIP database have only increased by $7 \%$ between the two periods.

\footnotetext{
69 One might argue that combining [D] and [E] produces a case count that is most directly comparable with the German figures. However, as discussed above, this is not entirely true because in Germany cases are not systematically split according to the number of patents at issue. In any case, even if we combine [D] and [E], the total case count reaches only slightly more than 500 cases.

70 www.darts-ip.com, last visited 05 Nov 2015.
} 
Table 5 Case outcome and duration, 2000-2008

\begin{tabular}{|c|c|c|c|c|c|c|c|}
\hline \multicolumn{2}{|c|}{ Jurisdiction } & \multicolumn{2}{|c|}{ Final judgement reached } & \multicolumn{4}{|c|}{ Duration in months $^{\mathrm{a}}$} \\
\hline & Claim & \# Cases & $\%$ & Mean & Median & Mean & Median \\
\hline \multirow[t]{4}{*}{$\mathrm{DE}$} & Infringement & 1982 & 43.1 & 13.6 & 10.9 & & \\
\hline & Revocation & 701 & 43.3 & 21.8 & 19.9 & & \\
\hline & Other & 475 & 39.5 & 10.2 & 7.2 & & \\
\hline & & & & & & \multicolumn{2}{|c|}{ No counterclaim $^{\mathrm{b}}$} \\
\hline \multirow[t]{3}{*}{ UK } & Infringement & 69 & 63.3 & 12.3 & 11.3 & 8.6 & 10.2 \\
\hline & Revocation & 59 & 72.8 & 10.8 & 11.2 & 10.3 & 11.1 \\
\hline & Other & 20 & 66.7 & 10.7 & 8.6 & 13.0 & 11.8 \\
\hline \multirow[t]{3}{*}{ FR } & Infringement & 704 & 83.7 & 29.5 & 24.2 & & \\
\hline & Revocation & 56 & 82.4 & 30.2 & 27.6 & & \\
\hline & Other & 151 & 68.3 & 19.3 & 19.8 & & \\
\hline \multirow[t]{3}{*}{$\mathrm{NL}^{\mathrm{c}}$} & Infringement & 254 & 97.3 & 14.9 & 10.1 & & \\
\hline & Revocation & 40 & 97.6 & 18.1 & 11.8 & & \\
\hline & Other & 0 & 0.0 & $\mathrm{Na}$ & $\mathrm{Na}$ & & \\
\hline
\end{tabular}

\footnotetext{
${ }^{a}$ Computed as difference between date when case was filed and first judgment. This includes cases where a decision on the request for a preliminary injunction is the final judgment of the case; that is, the preliminary injunction was not followed by a main proceeding

$\mathrm{b}$ Restricted to cases where either infringement or revocation at issue (no counterclaim)

c Most settled cases (an estimated 10-15\% of the total according to Graham and van Zeebroeck (2014)) are likely to be missing in our data
}

\subsection{Case-level comparison}

Table 5 cross-tabulates claims and information on whether a case ended with a court decision. We distinguish between infringement and revocation claims and an "other" category that contains other types of patent related claims such as entitlement, royalty payments etc. There are some interesting differences both within and across countries with regard to whether a case ends with a judgment on the merits.

In both France and Germany, there is no difference between the shares of infringement and revocation cases that are decided by judgment. In the UK, interestingly, a larger share of revocation than infringement cases is litigated through to judgment. In The Netherlands, almost all cases are decided by the court according to our data, but again it is likely we are missing most settled cases and the data for The Netherlands should therefore be interpreted with caution.

Other claims include disputes over employee inventions, royalty payments, the ownership of patents etc.

There are also substantial differences between jurisdictions: whereas in Germany around $43 \%$ of infringement and revocation actions end with a judgment on the merits, the shares in the UK and France are respectively $50 \%$ and almost $100 \%$ as large, regardless of the claim brought by claimants. However, recall that we may be 
missing some early settlements in these two countries. ${ }^{71}$ As mentioned above, the bifurcated system may encourage settlements either to avoid the dreaded "invalid but infringed" scenario or the invalidation of a patent, which would account for some of the observed differences in settlement rates.

Table 5 also shows average and median durations of cases until a first judgment on the merits of a case is handed down. We choose the first enforceable decision on the merits of the case to ensure time lags are comparable across jurisdictions. Decisions to appeal are endogenous to the differences in appeal procedures across countries.

The figures suggest that the median duration of an infringement case is shortest in the Netherlands (10.1 months), followed by Germany (10.9 months) and the UK (11.3 months). Infringement cases take a lot longer in France (24.2 months). Revocation actions take a lot longer to decide in Germany (19.9 months) and France (27.6 months) than in the UK (11.2 months) and The Netherlands (11.8 months).

The relatively fast decisions in infringement cases in Germany could be the outcome of courts focusing on the issue of infringement, relying on the assumption of validity. We have data on counterclaims for the UK that allow us to compare the duration of cases in the UK where only infringement or revocation were at issue (i.e., no counterclaims). However, the defendant's decision not to file a counterclaim is obviously an endogenous choice which means that the set of cases where no counterclaim is filed might have characteristics that are correlated with the duration of the case (and hence the figures may not be reliable). Regardless, Table 5 shows that the average case length for cases where only either infringement or revocation were at issue does not differ much relative to the broader set of cases that includes counterclaims (emphasis should be put on the median duration due to the small number of observations).

Table 6 cross-tabulates claims and their corresponding outcomes. There are large differences across jurisdictions with regard to case outcomes.

In Germany, about a fifth of infringement cases with a decision end with the judge holding a patent infringed (regardless of whether validity is challenged and the patent eventually held invalid by the BPatG). ${ }^{72}$ This share is a lot larger in The Netherlands (36\%). In France, in contrast, only a small share $(5.6 \%)$ of patents is held infringed (of cases that end with a judgment) and most patents are held valid (including cases where validity was not challenged) but not infringed, but again we

\footnotetext{
71 Our settlement rate in France is consistent with earlier findings by Véron (2010) and Graham and van Zeebroeck (2014), but is based on the same source of information: "ordonnances de mise en état". In case a dispute is settled before such an order is issued by the court (usually within a few weeks), it will not show up in our data.

72 In Germany some infringement proceedings contain more than one patent and all of the patents could be challenged individually in multiple revocation proceedings. This means that we summarize case outcomes such that there is only a single outcome for potentially several revocation cases corresponding to an infringement outcome. If there were more than one revocation proceeding on one particular patent with varying outcomes, we used the latest available outcome. If there were different outcomes in revocation proceedings on several patents that were all related to a single infringement case, we defined the outcome "revoked" when at least one patent was revoked. If there were multiple outcomes for the different patents, we always chose the court decision if available instead of a settlement (i.e., if one patent revocation action was settled and the other decided with a revocation, we code the case outcome as revocation).
} 
Table 6 Outcomes for infringement and revocation claims

\begin{tabular}{|c|c|c|c|c|c|c|c|c|c|}
\hline \multirow[t]{3}{*}{ Claim } & & \multicolumn{8}{|c|}{ Outcome } \\
\hline & & \multicolumn{2}{|c|}{ Infringed } & \multicolumn{2}{|c|}{$\begin{array}{l}\text { Not infringed/not } \\
\text { revoked }\end{array}$} & \multicolumn{2}{|c|}{ Revoked } & \multicolumn{2}{|c|}{ Settled } \\
\hline & & \# & $\%^{\mathrm{b}}$ & \# & $\%^{\mathrm{b}}$ & \# & $\%^{\mathrm{b}}$ & \# & $\%$ \\
\hline \multirow[t]{4}{*}{ Infringement only } & $\mathrm{DE}$ & 957 & 25.4 & 357 & 9.5 & & & 1811 & 48.1 \\
\hline & $\mathrm{FR}^{\mathrm{a}}$ & & & & & & & & \\
\hline & $\mathrm{NL}^{\mathrm{a}}$ & & & & & & & & \\
\hline & $\mathrm{UK}^{\mathrm{d}}$ & 3 & 7.1 & 6 & 14.3 & & & 24 & 57.1 \\
\hline \multirow[t]{4}{*}{ Revocation only } & $\mathrm{DE}$ & & & 134 & 14.3 & 278 & 29.7 & 436 & 46.6 \\
\hline & $\mathrm{FR}^{\mathrm{a}}$ & & & 45 & 66.2 & 11 & 16.2 & 12 & 17.6 \\
\hline & $\mathrm{NL}^{\mathrm{a}}$ & & & 11 & 26.8 & 29 & 70.7 & 1 & 2.4 \\
\hline & $\mathrm{UK}^{\mathrm{d}}$ & & & 10 & 20.8 & 17 & 35.4 & 14 & 29.2 \\
\hline \multirow{4}{*}{$\begin{array}{l}\text { Infringement and revocation } \\
\quad(\text { counterclaim })^{c}\end{array}$} & $\mathrm{DE}$ & 208 & 15.7 & 164 & 12.4 & 296 & 22.3 & 623 & 47.0 \\
\hline & $\mathrm{FR}^{\mathrm{a}}$ & 47 & 5.6 & 630 & 74.9 & 27 & 3.2 & 137 & 16.3 \\
\hline & $\mathrm{NL}^{\mathrm{a}}$ & 94 & 36.0 & 137 & 52.5 & 23 & 8.8 & 7 & 2.7 \\
\hline & $\mathrm{UK}^{\mathrm{d}}$ & 13 & 19.4 & 5 & 7.5 & 28 & 41.8 & 12 & 17.9 \\
\hline
\end{tabular}

Rows do not add up to $100 \%$. The difference is due to cases for which no outcome information is available and/or cases with "other" decisions, such as the refusal of an interim injunction or summary judgment

a Data not available or incomplete for FR and NL

b Percent of decided cases

${ }^{c}$ Counted as number of infringement claims

${ }^{\mathrm{d}}$ Britain

caution that our outcome data for France is incomplete and thus, these data should be interpreted with care.

In the UK, the large share of revoked patents is striking. A large share of claims challenges the validity of a patent without the validity challenge being triggered by an infringement claim. Among these cases, $35.4 \%$ end with the revocation of the patent at issue. The main reason for the high proportion of UK revocation cases relative to other countries is that since the 2001 case of Smithkline Beecham plc $v$ Generics $(U K)$ Ltd the UK has developed the principle of "clearing the way." The effect of this is that parties who are bringing products to market that could potentially infringe a competitor's patent(s) are encouraged to seek revocation of the competitor's patent(s), or alternatively, to seek a declaration of non-infringement. If they do so, they can avoid the possibility of an interim injunction being granted against them if the competitor decides to take patent infringement proceedings. Furthermore, also the revocation rate among cases that allege infringement is high $(41.8 \%)$. The share of infringement cases (that are decided by judgment) in Germany that end with revocation is significantly lower $(22.3 \%)$. This is perhaps surprising since in only about a third of all infringement 
cases the alleged infringer files a claim for revocation with the BPatG. ${ }^{73}$ One might expect that this selection mechanism increases the chances that, provided validity is challenged, the patent is indeed eventually revoked. Instead, most cases settle $(47.0 \%)$. This illustrates the possible effect of bifurcation on settlement behavior discussed above.

Table 7 lists the share of litigated patents according to the patent office that published/granted the patent right. Domestic patents account for $57.6 \%$ in Germany but for only $16.2 \%$ in the UK. The table also shows the share of litigated EPs that were validated in any of the four jurisdictions. ${ }^{74}$ The figures reveal that most EPs are validated in all four jurisdictions. The highest validation rate is found for Germany (93.4\% on average), which reflects the relatively large market size of the German economy within Europe. The lowest validation rate $(63.2 \%)$ is found for The Netherlands, which again reflects the relative (lower) importance of the Dutch economy. The large share of patents validated in all four jurisdictions underscores the fragmentation of the European patent system. While the same patent right is granted in several European jurisdictions, it has to be litigated in each jurisdiction separately.

Our data also allow us to identify cross-border litigation, i.e., cases that were litigated in multiple jurisdictions. That is, the same patent and the same claimants/ defendants are involved in separate court cases in different jurisdictions. Table 8 tabulates the number of parallel cases across the four jurisdictions. ${ }^{75}$ Because patents granted under the EPC are treated as national property rights in each validated member state of the EPC, they have to be enforced and invalidated in each jurisdiction separately. ${ }^{76}$ This raises concerns regarding the efficiency and costs of the system. Even more worryingly, despite the fact that all national parts of an EP have (at least initially) ${ }^{77}$ the same claims, court outcomes have often differed across jurisdictions. $^{78}$

\footnotetext{
73 This is significantly lower than in unified systems. For example, Helmers and McDonagh (2013a) show for the UK that in about $60 \%$ of cases alleging infringement, the defendant counter-claims for revocation.

74 We use legal status information to distinguish designation from validation; hence, we are able to tell whether a patent that was granted by the EPO became effective in an EPC member state.

75 This analysis is conducted on the patent level accompanied by identification of at least one common litigant in each of the jurisdictions.

76 See Articles 2 and 64(3) EPC.

77 After the opposition deadline has lapsed, the national parts of an EP patent can only be attacked separately before the national courts. Therefore, the claims of the national parts of the EP might change during these proceedings when certain claims are revoked.

78 Mejer and van Pottelsberghe de la Potterie (2012, pp. 226-232) report several case studies showing the diverging (inconsistent) decisions in different European jurisdictions regarding the same patent. Perhaps the most well-known case is that of Epilady v. Remington where infringement of Epilady's patent was found in Germany and the Netherlands but not in the UK and France.
} 
Table 7 Patent type and national validations

\begin{tabular}{|c|c|c|c|c|c|c|c|}
\hline \multirow[t]{3}{*}{ Jurisdiction } & \multirow[t]{3}{*}{ Domestic $(\%)$} & \multicolumn{5}{|l|}{ EPO } & \multirow[t]{3}{*}{ Other $(\%)$} \\
\hline & & \multirow[t]{2}{*}{$\%$} & \multicolumn{4}{|c|}{ Also validated in } & \\
\hline & & & $\mathrm{DE}$ & FR & NL & $\mathrm{UK}^{\mathrm{a}}$ & \\
\hline $\mathrm{DE}$ & 57.6 & 42.4 & & 88.6 & 57.7 & 85.5 & 0.0 \\
\hline FR & 58.8 & 38.7 & 89.3 & & 59.6 & 84.3 & 2.5 \\
\hline NL & 25.8 & 72.6 & 96.0 & 91.7 & & 89.9 & 1.6 \\
\hline $\mathrm{UK}^{\ddagger}$ & 16.2 & 80.6 & 94.8 & 96.0 & 72.4 & & 3.2 \\
\hline Average & & & 93.4 & 92.1 & 63.2 & 86.6 & \\
\hline
\end{tabular}

Validations in country where a patent is litigated may be less than $100 \%$ because in some cases, patents that have not yet been granted are subject to litigation

${ }^{a}$ Britain

Table 8 Parallel cases (2000-2008)

\begin{tabular}{|c|c|c|c|c|c|c|c|}
\hline & $\mathrm{DE}$ & FR & NL & $\mathrm{UK}^{\mathrm{b}}$ & Cases with parallel case ${ }^{\mathrm{a}}$ & Total cases $^{\mathrm{a}}$ & Share \\
\hline \multicolumn{8}{|c|}{ Parallel cases (same patent, either same claimant or defendant) } \\
\hline DE & & 102 & 71 & 61 & 1009 & 6427 & 15.7 \\
\hline FR & 816 & & 33 & 27 & 113 & 840 & 13.5 \\
\hline NL & 517 & 31 & & 38 & 92 & 302 & 30.5 \\
\hline $\mathrm{UK}^{\dagger}$ & 505 & 24 & 41 & & 84 & 165 & 50.9 \\
\hline Total & 1838 & 157 & 145 & 126 & & & \\
\hline \multicolumn{8}{|c|}{ Parallel cases (same patent and same claimant and defendant) } \\
\hline DE & & 34 & 24 & 21 & 127 & 5121 & 2.5 \\
\hline FR & 68 & & 16 & 13 & 51 & 840 & 6.1 \\
\hline NL & 46 & 16 & & 18 & 44 & 302 & 14.6 \\
\hline $\mathrm{UK}^{\mathrm{b}}$ & 35 & 14 & 19 & & 43 & $166^{\mathrm{c}}$ & 25.9 \\
\hline Total & 149 & 64 & 59 & 52 & & & \\
\hline
\end{tabular}

Parallel cases have been identified on the basis of patent numbers as well as claimants and defendants The table shows the number of parallel cases for each jurisdiction pair-a given case in jurisdiction $\mathrm{X}$ can correspond to multiple cases in jurisdiction Y for reasons discussed in Sects. 2 and 4.1. For example, 68 cases in Germany were also litigated in France; in France these 68 German cases correspond to only 34 cases

${ }^{\text {a }}$ For which patent numbers available

b Britain

${ }^{c}$ Exceeds number of cases where patents are available because 1 case was retrieved from references in UK court records to parallel cases in other jurisdictions

Table 8 shows parallel cases according to two definitions as explained in Sect. 3.6. The first type of parallel cases is less restrictive and means that the assignee of a patent is involved in law suits in several jurisdictions with potentially different adversaries. The second definition only captures cases where the claimant 
and defendant face each other in multiple jurisdictions over the same disputed patent-these are the cases that could be considered as duplication due to the fragmentation of the European enforcement system. Table 8 shows that the share of parallel cases is considerably larger for the broad definition of parallel cases. But even when we restrict the set of cases to the second, more restrictive definition, we still find a non-negligible number of parallel cases: 149 for Germany, 64 for France, 59 for The Netherlands, and 52 for the UK. If we count each case only once regardless of the number of cases in other jurisdictions it is involved in, we find for the UK and The Netherlands relatively larger shares of cases that are litigated in several jurisdictions (25.9\% in the UK and $14.6 \%$ in The Netherlands). Conversely, the rate of duplication among patents litigated in Germany is tiny (2.5\%). However, the number of cases in the UK and The Netherlands is considerably lower than in Germany, which determines the upper bound for the share of duplicated cases in Germany. ${ }^{79}$

Although overall the share of cases that are litigated in multiple jurisdictions is modest, perhaps the more important aspect of parallel litigation is consistency of outcomes when there is parallel litigation of the same case. Table 9 looks at the issue by cross-tabulating the case outcomes for parallel cases. ${ }^{80} \mathrm{We}$ find that only a small share of cases yields consistent outcomes across the jurisdictions in which they are litigated. Only around $28.6 \%$ of cases that are litigated in Germany and the UK reach the same outcome. The fraction is even lower for cases litigated in both Germany and The Netherlands $(22.7 \%)$. The interpretation of these numbers is difficult, however. For example, if infringement is found in Germany first, a settlement of the infringement proceedings in the UK may be an optimal response by both litigants. However, in case a patent is invalidated in Germany and then the corresponding parallel case in The Netherlands settled, the most likely invalid patent remains in force in The Netherlands.

These issues in combination with the systematic differences in the frequency of outcomes shown in Table 6 above imply that the timing of parallel cases may be important. Table 10 shows the share of parallel cases that were filed first in a given jurisdiction. The table shows that the only jurisdiction that stands out is The Netherlands with a disproportionately large share of parallel cases that are initiated there.

Finally, we focus on parallel cases that involve an EP and ask how many patents in absolute terms are involved in parallel disputes. Although there are parallel cases that involve national filings that belong to the same patent family, cases that involve EPs are of particular interest because the national incarnations of an EP can be expected to be (initially) identical and hence parallel litigation concerns exactly the same patent. Figure 5 shows the number of EPs that are involved in parallel

\footnotetext{
79 Roughly, even if every case litigated in France, the Netherlands, and the UK were duplicated in Germany, the share of duplicated cases would not exceed $25 \%$.

${ }^{80}$ We show in Table 9 only the statistics for parallel cases that involve Germany mainly because this provides the largest number of parallel cases. Appendix Table 15 shows statistics also for the other country-combinations.
} 
Table 9 Outcomes of German cases with parallel case in UK, France and Netherlands (2000-2008)

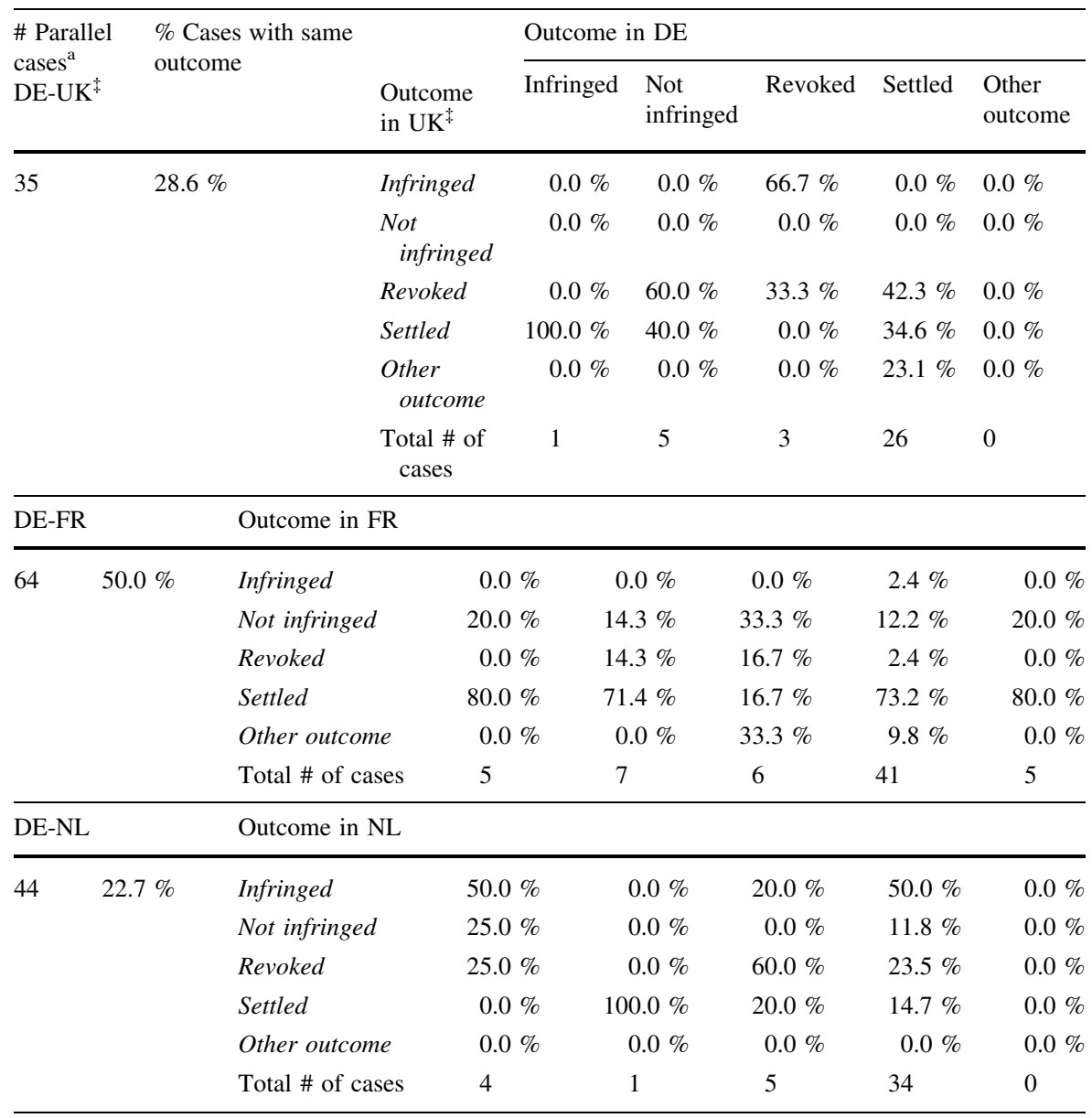

Parallel cases have been identified on the basis of patent numbers as well as claimants and defendants Columns for each jurisdiction-pair add up to $100 \%$; for example, of all parallel cases in DE-UK where infringement was found in Germany $(100 \%), 66.7 \%$ of these parallel cases in the UK held the patent infringed and $33.3 \%$ revoked the patent in the UK

a Number of cases for which information on case outcome available

litigation. The figure shows that the majority of EPs are involved in parallel disputes in only two jurisdictions, above all in Germany and France. Nevertheless, there are a substantial number of EPs that are litigated in three jurisdictions, above all Germany, France, and The Netherlands. It is noteworthy that only a negligible number of EPs are litigated in all four jurisdictions in parallel proceedings. 
Table 10 Parallel cases (2000-2008)

\begin{tabular}{lllll}
\hline $\begin{array}{l}\text { Jurisdiction where claim } \\
\text { filed }\end{array}$ & $\begin{array}{l}\text { Filed first in DE } \\
(\%)\end{array}$ & $\begin{array}{l}\text { Filed first in FR } \\
(\%)\end{array}$ & $\begin{array}{l}\text { Filed first in NL } \\
(\%)\end{array}$ & $\begin{array}{l}\text { Filed first in UK } \\
(\%)^{\text {b }}\end{array}$ \\
\hline Filed second in DE & & 54.8 & 59.2 & 41.7 \\
Filed second in FR & 45.8 & & 55.6 & 57.1 \\
Filed second in NL & 41.3 & 38.9 & 63.2 & 36.8 \\
Filed second in UK & 58.3 & 42.9 & 63 & \\
\hline
\end{tabular}

Parallel cases have been identified on the basis of patent numbers as well as claimants and defendants The table shows the share of parallel cases for jurisdiction-pairs that was initiated in a given jurisdiction (based on exact filing date of the initial claim). $100 \%$ is sum of "filed first in X" plus "filed second in X", for example, "filed first in UK" $41.7 \%+$ "filed second in UK" $58.3 \%=100 \%$

${ }^{\text {a }}$ Britain

b Sum of FR-NL and NL-FR is less than $100 \%$ because 1 case was filed on the same date in both jurisdictions

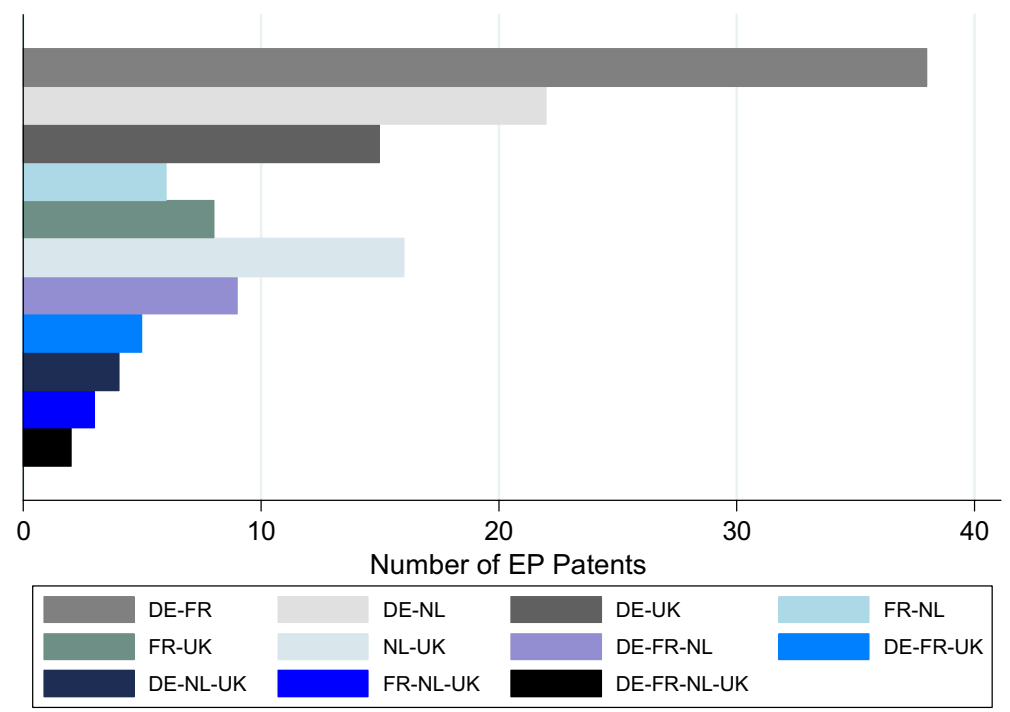

Fig. 5 Parallel cases and EP counts. Notes: the figure shows the number of EPs that are litigated in multiple jurisdictions. Data covers patent cases filed between 2000 and 2008

\section{Conclusion}

With the UPC and unitary patent soon to come into being, the European patent system is about to undergo systemic change. These institutional reforms have been greeted with cautious optimism within the legal and business communities, though several concerns remain, particularly with regard to the consistency of decision making at the UPC as well as the cost of using the UPC and of obtaining unitary 
patents (McDonagh 2014). As we noted at the outset, discussions concerning the reforms of the European patent system-and especially the discourse regarding changes to the legal and procedural framework of patent enforcement-have been characterized by a striking lack of representative quantitative evidence. In this context, our analysis in this article contributes to this ongoing debate by offering new and comprehensive empirical evidence based on a novel dataset that covers patent enforcement in four jurisdictions in Europe: Germany, the UK (England and Wales), France, and The Netherlands.

We also note that for a variety of legal and procedural reasons, European legal systems are not set up to provide easy access to case information. Therefore, these data had to be collected from a wide range of sources, including information from handwritten case records at regional courts (in Germany), online case repositories (for the UK) and private data providers (for France and The Netherlands). Given that this is the first authoritative study of its kind, we developed a methodology that allowed us to transform largely qualitative information collated from court records into quantitative measures that are comparable across jurisdictions. The analysis of this novel dataset uncovers a number of interesting differences in patent litigation patterns across the different jurisdictions.

Our results show that the number of cases heard by German regional courts exceeds by some distance the number of cases heard in the other three jurisdictions. This result holds even after accounting for macro-economic indicators related to the size of the German economy, such as total research and development (R\&D) spending. Even when we account for the over-counting of cases-which occurs largely due to bifurcation, idiosyncratic practices at regional courts and procedural differences, as well as taking into account the relative size of the economy-the number of cases in Germany exceeds the combined number of cases in the other three jurisdictions over the same time period.

Our data reveal substantial differences across jurisdictions in the outcomes of cases that were decided by a judgment on the merits of the case. For example, in cases decided 2000-2008 the UK stands out with a relatively large share of revoked patents, even when the original claim was for infringement. In Germany, the share of patents involved in an infringement suit that are ultimately revoked by the Federal Patent Court is low, a mere 9.2\%. This reflects partly the fact that only in around a third of infringement cases filed 2000-2008 did the defendant file a claim for revocation at the Federal Patent Court. It also reflects the existence of relatively large incentives for the claimant and defendant to settle the revocation proceedings before a full hearing at the Federal Patent Court. This helps to explain the comparatively low share of infringement claims that face a counterclaim for invalidity and the low share of invalidity challenges actually decided by the Federal Patent Court (Cremers et al. 2014).

Thus, in the UK, revocation is the most likely outcome regardless of whether the initial claim is for infringement or revocation; and with its emphasis on discovery and the use of expert opinions, the data for 2000-2008 indicate that the UK courts offer a favourable setting to invalidate a patent. By contrast, infringement is a particularly likely outcome at the German courts, which is due in part to the 
bifurcated system where LGs focus only on deciding infringement claims, something that contributes to Germany's reputation as a "patent friendly" jurisdiction.

To some extent this explains the popularity of Germany as a patent litigation venue. In other words, the existence of German bifurcation is not the sole reason for the disparity in case volumes across the four jurisdictions. Additional reasons for Germany's patent litigation dominance include the fact that (i) obtaining an injunction against a potential infringer in Germany can severely affect that competitor's ability to market products successfully in the EU; and (ii) the German courts have a patentee-friendly reputation, i.e., Germany is seen as the "go to" jurisdiction to obtain an injunction against an infringer on a speedy, cost-effective basis. This can be contrasted with e.g. the UK which traditionally has been seen as an "anti-patent" jurisdiction, with revocation a likely case outcome, and one that suits parties who wish to revoke patents rather than parties whose patents have been infringed. These reputations are shown in our results to be largely accurate for 2000-2008.

Our data additionally allow us to compare across jurisdictions how long it takes courts to reach a first instance decision on the merits of the case- a crucial issue with respect to the UPC, given that one of the intentions behind the UPC is to provide a speedier litigation system. Patent proceedings take around 2 years in France, but are substantially faster in the other three jurisdictions. We find that the median durations for infringement cases are 11 months in Germany, 10 months in The Netherlands, and 11 months in the UK. Claims for revocation (patent invalidity) are decided fastest in the UK (within less than a year), but take considerably longer in Germany (on average 22 months).

In addition, with respect to comparisons between Germany and the UK, the fact that we possess detailed information for cases in the UK enables us to gauge whether decisions in Germany are relatively faster because of bifurcationGerman courts decide only on either the issue of infringement or the issue of revocation. This is done by looking only at cases in the UK where no attack on the validity was raised (either as a defence or as a counterclaim), and hence, where the court focused solely on the claim brought by the claimant. Interestingly, our results indicate that focusing on a single issue does not appear to have any substantial effect on the median duration of a case in the UK. Nevertheless, if the validity of a patent is challenged in Germany at the Federal Patent Court, the judgment of the validity case is commonly handed down with a substantial lag relative to the judgment of the infringement case; moreover, the validity challenge is usually filed a few months into the infringement case which can increase the length of the overall dispute. ${ }^{81}$ Therefore, the total length of a patent dispute in Germany, if the alleged infringer challenges validity at the Federal Patent Court,

\footnotetext{
81 The fact that invalidity claims can only be filed at the Federal Patent Court after an opposition at the German Patent and Trademark Office (DPMA) or the EPO (or after the period for an opposition has expired) may further delay the decision on validity.
} 
takes a lot longer (on average 24 months) than in cases just involving infringement. Thus, with respect to Germany, while bifurcation has the advantage that it allows the infringement courts to focus on a single issue, the fact that invalidity claims are filed with the BPatG a few months after the infringement claim-coupled with the fact that the BPatG takes a relatively long time to rule on validity claims-causes considerable delays to the conclusion of a case in Germany, something that provides strong incentives to parties to settle the invalidity challenge out of court (even where there is a strong claim the patent is invalid). Slightly less than $60 \%$ of cases in Germany end with a settlement, whereas this is true for only around $35 \%$ of cases in the UK. On this point, we note that similar incentives to settle invalidity challenges, even where the alleged infringer thinks the patent is invalid, could emerge within the UPC system in cases where bifurcation occurs. However, given the limits that have been imposed on case length at the UPC, coupled with the crucial fact that bifurcation will be optional at the UPC - not mandatory as it is in Germany-it seems unlikely that incentives to settle (where there is a strong claim the patent is invalid) will develop into a serious problem with respect to the UPC.

We also demonstrate that the number of cases has increased in the UK and Germany over time 2000-2008, but there is no evidence for an upward trend in case filings in France and The Netherlands during this period. ${ }^{82} \mathrm{We}$ cannot give a definite explanation for why certain jurisdictions feature case loads which are on the increase and others do not, but, as noted above, Germany's increasing case load over time probably shows that its reputation for cost-effective, speedy patentfriendly litigation continues to spread. Meanwhile, the value of the UK as a venue for high-quality hearings and decisions on validity makes it a popular venue for litigants who wish to "clear the way" of potentially disruptive patents. ${ }^{83}$

We also provide insights regarding one of the other main motivations for the current reforms of the European patent system: addressing the fragmentation of patent litigation in Europe. We show that most EPO-granted patents (EPs) that are litigated in a given jurisdiction have also been validated in all other jurisdictions (with the possible exception of The Netherlands). This means that at present there is definite scope for parallel (fragmented) litigation of the same patent in multiple jurisdictions within Europe. We also offer direct evidence of the fragmentation of

\footnotetext{
82 Qualitatively, our results are broadly consistent with those provided by Graham and van Zeebroeck (2014): first, the orders of magnitude of litigation cases per country and country shares in total litigation are, in general, qualitatively consistent across the two papers - notably, in terms of outcomes, leaving settlements aside, our results for Germany and the UK in particular are qualitatively similar to the GVZ article; second, our findings on multi-country litigation complement and refine the findings of the earlier work by GVZ - our results confirm the relative share of each country in multi-country cases found in the GVZ article, but we are able to offer more complete information by identifying nearly twice as many multi-country cases as reported in GVZ (thanks to our more complete coverage of cases in Germany, where many of these complex cases occur); finally, as with the GVZ paper, we find that where parallel litigation occurs in different jurisdictions it often leads to different case outcomes.

${ }^{83}$ More recent data for the UK also show a very substantial increase in case filings from 2010 onward (Helmers et al. 2015), which means the trends observed for the 2000-2008 period are difficult to interpret.
} 
the European patent system. In the UK and The Netherlands we find a relatively high number of cases that are litigated in several jurisdictions (26 and $15 \%$ of all cases litigated in the UK and The Netherlands respectively). These shares are a lot lower in Germany (2\%) and France (6\%). These differences are partly explained by the fact that the overwhelming share of patents litigated in the UK and The Netherlands are national parts of European Patents (EPs) (81 and $73 \%$ respectively) that have also been validated in Germany and France. The share of litigated EPs is a lot lower in Germany and France (48 and $39 \%$ respectively). If we restrict attention to EPs only, overall the incidence of duplication is small: only $8.4 \%$ of all litigated EPs are subject to litigation in more than one country. Most of these EPs are litigated only in two jurisdictions-we show that the number of patents litigated in all four jurisdictions is negligible.

Crucially, we find that patents affected by duplicate/parallel litigation appear to be particularly important, complex and valuable, and as a result the cases are likely to be more resource-intensive than those concerning other patents. We also show that the case outcomes of these parallel cases vary substantially across jurisdictions. Only around a quarter of cases that are litigated both in Germany and the UK, or in Germany and The Netherlands reach the same outcome. This is important because it results in situations where the national counterpart of an EP may be invalidated in one jurisdiction, yet in the parallel case a settlement may arise. This gives weight to the argument that there is a need for greater legal certainty and unity of decision-making in the context of patent litigation in Europe. Nonetheless, quantifying the uncertainty and cost of duplication that arises from such parallel litigation will require further work. Furthermore, the UPC court fees have yet to be finalised so it is not possible to accurately estimate a comparison regarding parallel litigation at present and in the future when the UPC comes into play. However, the modest share of EPs that are litigated in parallel may demonstrate that the supposed cost-savings of the UPC could be more modest than the proponents of the UPC suggest, i.e., if, at present, many patentees only need to litigate in Germany then why is the wider remit of the UPC required? On the other hand, it is plausible that parallel litigation may at present be discouraged due to the complexities (and cost uncertainties) inherent in pursuing litigation across multiple jurisdictions, something which will be reduced by the UPC. In other words, the UPC may help to create a market for cross-border patent enforcement across the UPC member states (McDonagh 2014).

Moreover, looking ahead to the UPC, we note that a striking figure emerges from Table 9-in cases of parallel litigation of the same patent(s) settlements in Germany do not necessarily facilitate settlements in other jurisdictions (except, perhaps in France). Thus, although the German system appears to be particularly conducive to settlements, settlements are seldom achieved when the same patent disputes are heard in front of other European courts, especially the UK and The Netherlands. This may indicate the difficulties inherent in agreeing on settlement while parallel litigation is ongoing - it may be the case that, given the variances in outcomes of cases taken in Germany and the UK in particular, parties may persist 
in litigation at one venue even where they have settled the dispute elsewhere. The centralised, unified enforcement promised by the UPC may, in such circumstances, lead to more unity of settlements across Europe-but probably only after the transitional period of shared jurisdiction between national courts and the UPC has ended.

Hence, in conclusion we observe a number of potential benefits of the UPC: (i) the centralization of patent cases via the UPC will reduce differences in legal procedures concerning patent enforcement across various European jurisdictions, giving litigants greater legal clarity regarding procedures; (ii) the UPC may also increase the speed of decision-making-for instance, our findings suggest that only allowing for bifurcation under certain restrictive conditions (as envisaged by the UPC Agreement) may increase the speed to reach a decision as well as the share of invalidity claims that are decided by the court instead of settled; (iii) the existence of UPC litigation will level the costs involved in patent proceedings, which currently differ vastly across jurisdictions (moreover, substantial costs may be accrued by enforcing or challenging the validity of the same EP in multiple jurisdictions); (iv) the UPC will in the long term eliminate the need for parallel litigation involving EPs and UPs-and thus, it will help patentees and users of technology to avoid the legal and business uncertainties that result from the existence of different outcomes of cases concerning the same patent in different jurisdictions; and (v) the UPC may therefore facilitate an increase in the unity of patent settlements across Europe, cutting down on situations where a settlement is reached in one jurisdiction, but litigation continues in the other(s).

Acknowledgment Open access funding provided by Max Planck Society.

Open Access This article is distributed under the terms of the Creative Commons Attribution 4.0 International License (http://creativecommons.org/licenses/by/4.0/), which permits unrestricted use, distribution, and reproduction in any medium, provided you give appropriate credit to the original author(s) and the source, provide a link to the Creative Commons license, and indicate if changes were made.

\section{Appendix}

See Tables 11, 12, 13, 14 and 15. 


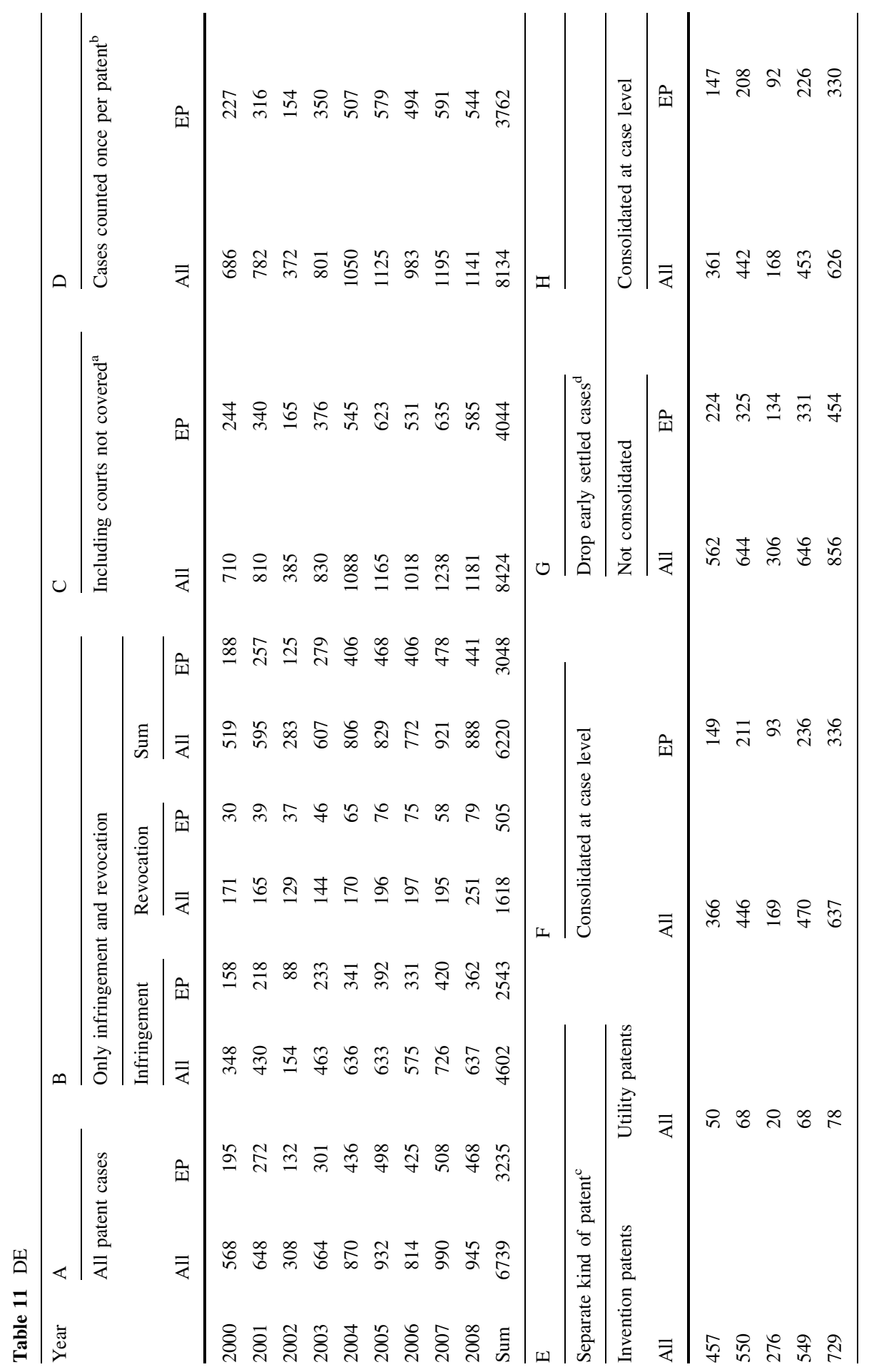




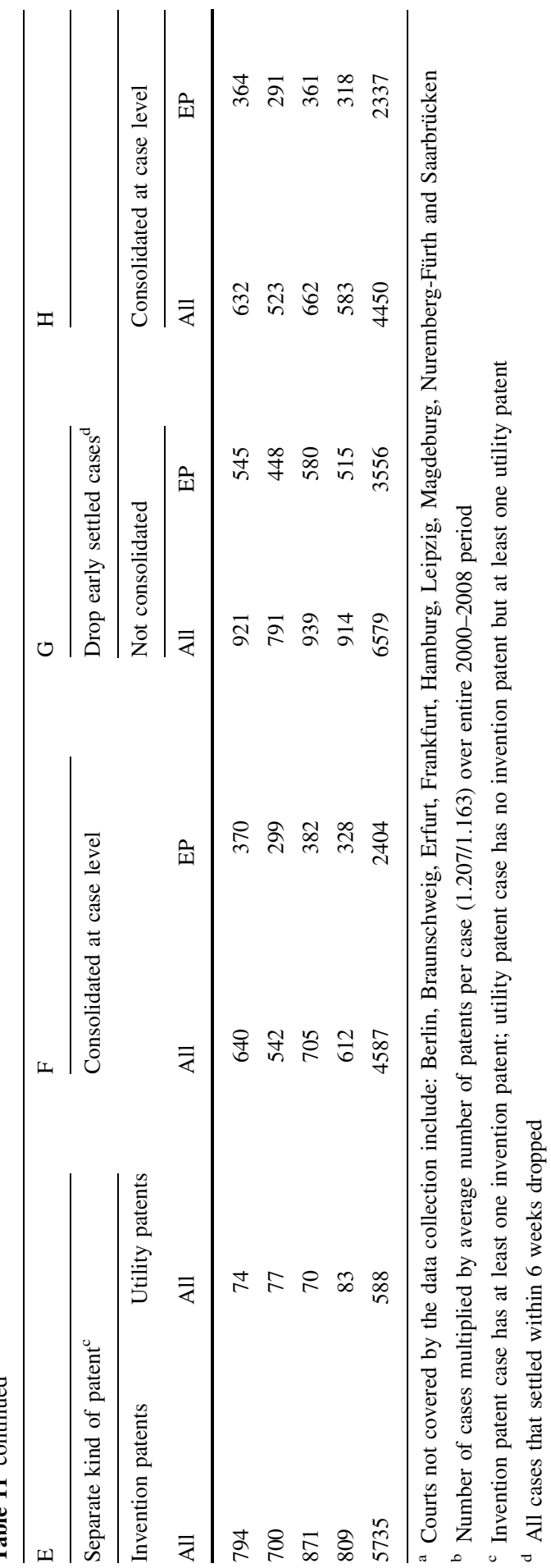




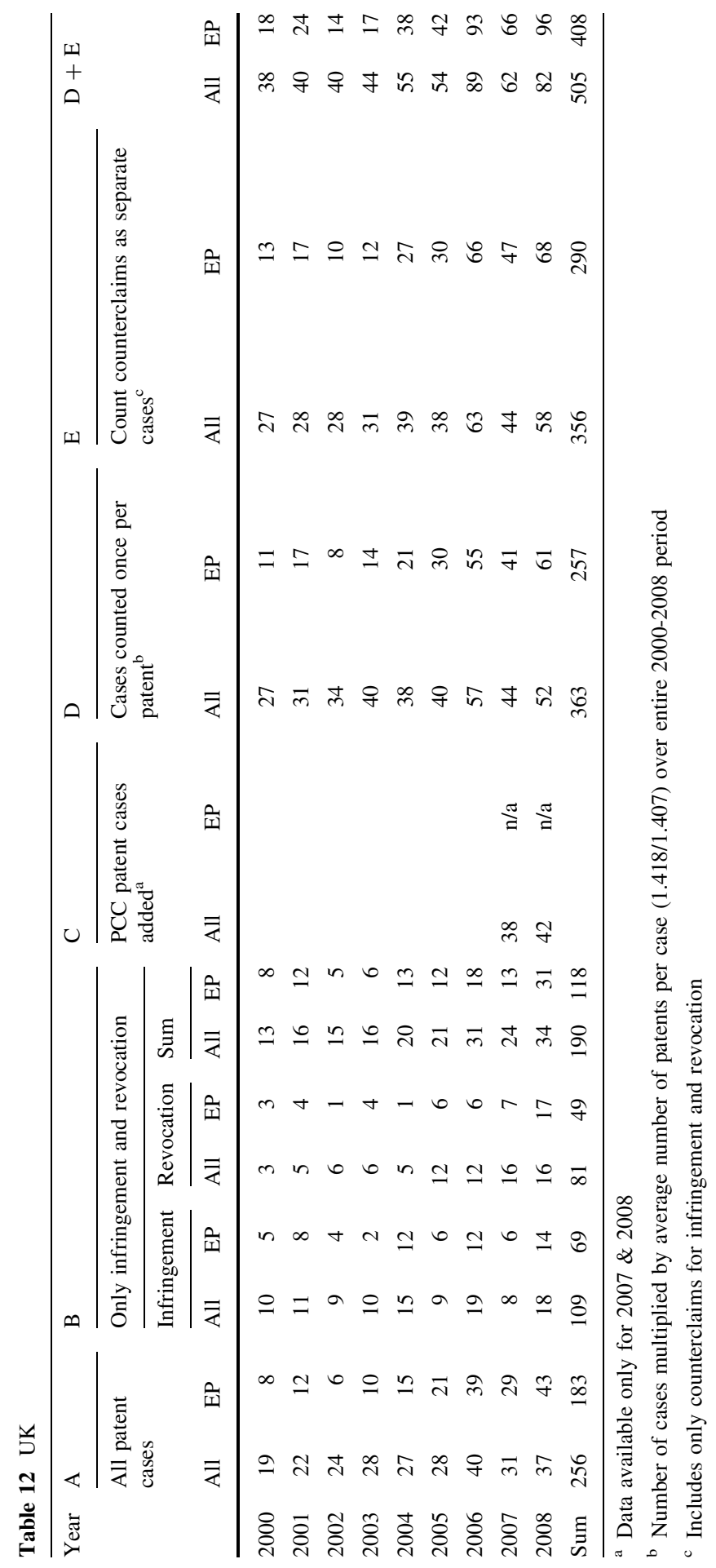


Table 13 FR

\begin{tabular}{|c|c|c|c|c|c|c|c|c|c|c|c|c|}
\hline \multirow[t]{4}{*}{ Year } & \multicolumn{2}{|l|}{ A } & \multicolumn{6}{|l|}{ B } & \multicolumn{2}{|l|}{$\mathrm{C}$} & \multicolumn{2}{|l|}{$\mathrm{D}$} \\
\hline & \multirow{2}{*}{\multicolumn{2}{|c|}{$\begin{array}{l}\text { All patent } \\
\text { cases }\end{array}$}} & \multicolumn{6}{|c|}{ Only infringement and revocation } & \multirow{2}{*}{\multicolumn{2}{|c|}{$\begin{array}{l}\text { Courts not } \\
\text { covered }^{\mathrm{a}}\end{array}$}} & \multirow{2}{*}{\multicolumn{2}{|c|}{$\begin{array}{l}\text { Cases counted once } \\
\text { per patent }{ }^{\mathrm{b}}\end{array}$}} \\
\hline & & & \multicolumn{2}{|c|}{ Infringement } & \multicolumn{2}{|c|}{ Revocation } & \multicolumn{2}{|c|}{ Sum } & & & & \\
\hline & All & EP & All & EP & All & $\mathrm{EP}$ & All & $\mathrm{EP}$ & All & $\mathrm{EP}$ & All & EP \\
\hline 2000 & 106 & 61 & 79 & 52 & 6 & 3 & 85 & 55 & 159 & 91.5 & 212 & 122 \\
\hline 2001 & 126 & 58 & 89 & 47 & 8 & 6 & 97 & 53 & 189 & 87 & 252 & 116 \\
\hline 2002 & 125 & 61 & 82 & 50 & 7 & 2 & 89 & 52 & 187.5 & 91.5 & 250 & 122 \\
\hline 2003 & 85 & 43 & 57 & 36 & 3 & 2 & 60 & 38 & 127.5 & 64.5 & 170 & 86 \\
\hline 2004 & 120 & 60 & 95 & 48 & 8 & 7 & 103 & 55 & 180 & 90 & 240 & 120 \\
\hline 2005 & 118 & 87 & 80 & 78 & 8 & 3 & 88 & 81 & 177 & 130.5 & 236 & 174 \\
\hline 2006 & 129 & 70 & 103 & 58 & 4 & 8 & 107 & 66 & 193.5 & 105 & 258 & 140 \\
\hline 2007 & 106 & 64 & 81 & 51 & 12 & 9 & 93 & 60 & 159 & 96 & 212 & 128 \\
\hline 2008 & 87 & 52 & 68 & 41 & 7 & 5 & 75 & 46 & 130.5 & 78 & 174 & 104 \\
\hline Sum & 1002 & 556 & 734 & 461 & 63 & 45 & 797 & 506 & 1503 & 834 & 2004 & 1112 \\
\hline
\end{tabular}

a Courts not covered by the survey include: Lyon, Rennes, Lille, Marseille, Bordeaux, Strasbourg, Toulouse, Nancy, Limoges, Autres

b Number of cases multiplied by medium number of patents per case (2.00) over entire 2000-2008 period

Table $14 \mathrm{NL}$

\begin{tabular}{|c|c|c|c|c|c|c|c|c|c|c|}
\hline \multirow[t]{4}{*}{ Year } & \multicolumn{2}{|l|}{ A } & \multicolumn{6}{|l|}{ B } & \multicolumn{2}{|l|}{ D } \\
\hline & \multirow{2}{*}{\multicolumn{2}{|c|}{ All patent cases }} & \multicolumn{6}{|c|}{ Only infringement and revocation } & \multicolumn{2}{|c|}{ Cases counted once per patent ${ }^{\mathrm{a}}$} \\
\hline & & & \multicolumn{2}{|c|}{ Infringement } & \multicolumn{2}{|c|}{ Revocation } & \multicolumn{2}{|c|}{ Sum } & \multirow[t]{2}{*}{ All } & \multirow[t]{2}{*}{ EP } \\
\hline & All & EP & All & EP & All & $\mathrm{EP}$ & All & EP & & \\
\hline 2000 & 42 & 28 & 36 & 24 & 3 & 3 & 39 & 27 & 56 & 38 \\
\hline 2001 & 40 & 23 & 33 & 21 & 1 & 1 & 34 & 22 & 54 & 31 \\
\hline 2002 & 31 & 22 & 29 & 20 & 1 & 1 & 30 & 21 & 42 & 30 \\
\hline 2003 & 19 & 11 & 13 & 9 & 4 & 2 & 17 & 11 & 26 & 15 \\
\hline 2004 & 45 & 28 & 33 & 23 & 8 & 3 & 41 & 26 & 61 & 38 \\
\hline 2005 & 40 & 28 & 30 & 22 & 7 & 5 & 37 & 27 & 54 & 38 \\
\hline 2006 & 35 & 18 & 34 & 17 & 1 & 1 & 35 & 18 & 47 & 24 \\
\hline 2007 & 36 & 14 & 27 & 12 & 6 & 1 & 33 & 13 & 48 & 19 \\
\hline 2008 & 38 & 26 & 24 & 19 & 9 & 3 & 33 & 22 & 51 & 35 \\
\hline Sum & 326 & 198 & 259 & 167 & 40 & 20 & 299 & 187 & 438 & 266 \\
\hline
\end{tabular}

${ }^{a}$ Number of cases multiplied by average number of patents per case (1.345) over entire 2000-2008 period 
Table 15 Share of parallel cases with same outcome (2000-2008)

\begin{tabular}{|c|c|c|c|c|}
\hline & $\mathrm{DE}(\%)$ & $\mathrm{FR}(\%)$ & NL (\%) & UK (\%) \\
\hline \multicolumn{5}{|l|}{$\mathrm{DE}$} \\
\hline FR & 50.00 & & & \\
\hline NL & 22.73 & 16.67 & & \\
\hline $\mathrm{UK}^{\mathrm{a}}$ & 28.57 & 33.33 & 36.84 & \\
\hline
\end{tabular}

Parallel cases have been identified on the basis of patent numbers as well as claimants and defendants (same patent, either same claimant or defendant)

${ }^{a}$ Britain

\section{References}

Ann, C. (2009). Verletzungsgerichtsbarkeit zentral für jedes Patentsystem und doch häufig unterschätzt. GRUR-Gewerblicher Rechtsschutz und Urheberrecht, 111(3), 205-209.

Bardehle. (2013). Patent infringement proceedings. http://www.bardehle.com/fileadmin/content documents/broschures/Patent_Infringement_Proceedings.pdf. last visited 05 Nov 2015.

Brinkhof, J. (2000). The enforcement of patent rights in The Netherlands, international review of industrial property and copyright law (IIC) 2000, pp. 706-722.

CMS. (2013). International patent litigation guide, May 2013. http://www.cmslegal.com/ patentswithoutborders/patentlitigationwithoutborders/pages/default.aspx. Last visited 05 Nov 2015.

Cremers, K., Gaessler, F., Harhoff, D., Helmers, C., \& Lefouili, Y. (2014). Invalid but infringed? An analysis of Germany's bifurcated patent litigation system. Max Planck Institute for Innovation \& Competition Research Paper No. 14-14.

Freshfields. (2011). A guide to patent litigation in England and Wales. http://www.lexology.com/library/ detail.aspx?g=6bd0f5bc-df2c-4578-8102-02c6d3c9946f. Last visited 05 Nov 2015.

Graham, S., \& van Zeebroeck, N. (2014). Comparing patent litigation across Europe: A first look, 17 Stan. Tech. L. Rev. 655.

Harhoff, D. (2009). Economic cost-benefit analysis of a unified and integrated European patent litigation system. Final report tender no. MARKT/2008/06/D.

Helmers, C., Lefouili, Y., \& McDonagh, L. (2015). Evaluation of the reforms of the intellectual property enterprise court 2010-2013. A report commissioned by the UK intellectual property office. http:// www.gov.uk/government/news/independent-review-finds-ipec-reforms-have-improved-access-tojustice. Last visited 05 Nov 2015.

Helmers, C., \& McDonagh, L. (2013a). Patent litigation in the UK-An Empirical Survey 2000-2008. Journal of Intellectual Property Law \& Practice, 8(11), 846-861.

Helmers, C., \& McDonagh, L. (2013b). Patent litigation in England and Wales and the issue-based approach to costs. Civil Justice Quarterly, 32(3), 369-384.

Hogan Lovells. (2013). Patent litigation guide. http://limegreenip.hoganlovells.com/patents/patent litigation/Pages/default.aspx. Last visited 05 Nov 2015.

Klos, M. (2010). Standortvorurteil. JUVE Rechtsmarkt, 13(4), 72-83.

Kühnen, T., \& Claessen, R. (2013). Die Durchsetzung von Patenten in der EU-Standortbestimmung vor Einführung des Europäischen Patentgerichts. GRUR, 115(6), 592-596.

Ladas \& Perry. (2002). Patent litigation in France. http://www.ladas.com/Litigation/ForeignPatent Litigation/France_Patent_Lit.html. Last visited 22 Sept 2013.

Land. (2010). Patent litigation in The Netherlands. In IAM-magazine, patents in Europe 2010/2012, pp. 61-64. ISSN 1741-1424. http://www.iam-magazine.com/issues/SupplementArticles.aspx?g= ad1035f3-895e-435e-b9d3-283cb9aaa033. Last visited 22 Sept 2013.

McDonagh, L. (2014). Exploring perspectives of the unified patent court and the unitary patent within the business and legal communities, a report commissioned by the UK intellectual property office. https://www.gov.uk/government/publications/exploring-perspectives-of-the-up-and-upc

Mejer, M., \& van Pottelsberghe de la Potterie, B. (2012). Economic incongruities in the European patent system. European Journal of Law and Economics, 34(1), 215-234. 
Moss, G., Jones, M., \& Lundie-Smith, R. (2010). Just how 'anti-patent' are the UK courts?,' Journal of Intellectual Property Law \& Practice, 5(3), 148-157.

Reiman, M. (2012). Cost and fee allocation in civil procedure-A Comparative Study. New York: Springer.

Reinganum, J. F., \& Wilde, L. L. (1986). Settlement, litigation, and the allocation of litigation costs. Rand Journal of Economics, 17(4), 557-566.

Spier, K. (1992). The dynamics of pretrial negotiation. The Review of Economic Studies, 59(1), 93-108.

Stauder, D. (1983). Die tatsächliche Bedeutung von Verletzungs- und Nichtigkeitsverfahren in der Bundesrepublik Deutschland, Frankreich, Großbritannien und Italien: Ergebnisse einer statistischempirischen Untersuchung. GRUR-Gewerblicher Rechtsschutz und Urheberrecht international (GRUR Int.) 1983, Vol. 31(4), pp. 233-242.

Swens, O., \& Reijns, A. (2011). Claiming damages for patent infringement in the Netherlands, Mitteilungen der deutschen Patentanwälte, 102(8), 407-410.

van Pottelsberghe de la Potterie, B. (2009). Lost property: The European patent system and why it doesn't work. Bruegel Blueprint No. 9, Brussels.

Véron, P. (2002). Patent infringement litigation in France. Mitteilungen der deutschen Patentanwälte, 93, 386-403.

Véron, P. (2010). Le contentieux des brevets d'invention en France. http://www.veron.com/publications/ Colloques/Stats_contentieux_brevets_France_2000-2009_Veron_et_Associes.pdf. Last visited 05 Nov 2015. 